\title{
Application of Life Cycle Energy Assessment in Residential Buildings: A Critical Review of Recent Trends
}

\author{
Hossein Omrany ${ }^{1}$, Veronica Soebarto ${ }^{1}{ }^{\mathbb{D}}$, Ehsan Sharifi ${ }^{1}$ and Ali Soltani ${ }^{2,3, *}$ \\ 1 School of Architecture \& Built Environment, University of Adelaide, Adelaide SA 5005, Australia; \\ hossein.omrany@adelaide.edu.au (H.O.); veronica.soebarto@adelaide.edu.au (V.S.); \\ ehsan.sharifi@adelaide.edu.au (E.S.) \\ 2 School of Art, Architecture and Design, University of South Australia, Adelaide SA 5001, Australia \\ 3 School of Art and Architecture, Shiraz University, Shiraz 71946-84471, Iran \\ * Correspondence: Ali.Soltani@unisa.edu.au
}

Received: 24 November 2019; Accepted: 30 December 2019; Published: 1 January 2020

\begin{abstract}
Residential buildings are responsible for a considerable portion of energy consumption and greenhouse gas emissions worldwide. Correspondingly, many attempts have been made across the world to minimize energy consumption in this sector via regulations and building codes. The focus of these regulations has mainly been on reducing operational energy use, whereas the impacts of buildings' embodied energy are frequently excluded. In recent years, there has been a growing interest in analyzing the energy performance of buildings via a life cycle energy assessment (LCEA) approach. The increasing amount of research has however caused the issue of a variation in results presented by LCEA studies, in which apparently similar case studies exhibited different results. This paper aims to identify the main sources of variation in LCEA studies by critically analyzing 26 studies representing 86 cases in 12 countries. The findings indicate that the current trend of LCEA application in residential buildings suffers from significant inaccuracy accruing from incomplete definitions of the system boundary, in tandem with the lack of consensus on measurements of operational and embodied energies. The findings call for a comprehensive framework through which system boundary definition for calculations of embodied and operational energies can be standardized.
\end{abstract}

Keywords: life cycle energy assessment; life cycle assessment; residential buildings; energy efficiency; sustainability

\section{Introduction}

The residential sector is responsible for consuming $27 \%$ of energy and emitting $17 \%$ of the greenhouse gas (GHG) emissions worldwide [1,2]. This percentage differs between countries due to varying climatic conditions, energy requirements, social and economic situations, and the availability of main energy resources [3]. Due to the significance of this sector in mitigating global climate change, considerable efforts have been undertaken across many countries to reduce energy consumption in residential buildings by legislating various regulations and building codes. These regulations are mainly in place to minimize the environmental impacts associated with energy use from heating, cooling, and lighting [4]. However, recent studies have shown the reduction of building operational energy use can lead to an increase in total building life cycle energy use due to increasing the embodied energy from the building components [5-8]. Therefore, research into investigating embodied energy using the life cycle energy assessment (LCEA) approach has been increasing in recent years, with numerous detailed case studies of individual buildings developed by academics. 
The LCEA is a simplified version of the life cycle assessment (LCA), which only accounts for energy inputs at different stages of the life cycle, including both embodied energy and operational energy [9]. The increasing amount of research has however caused an issue of variations in results presented by LCEA studies, in which apparently similar case studies exhibited different results. To date, a plethora of studies have been conducted exploring reasons for variations in the results of LCEA studies [4,10-13]. For instance, Dixit et al. [10] identified key parameters which can lead to varying results in embodied energy analysis, namely system boundary definitions, the methods used for measurement of embodied energy, geography, the type of energy (i.e., primary or secondary energy), age and source of data, data completeness, manufacturing technology, feedstock energy considerations, and temporal representativeness.

The majority of the conducted studies only looked at parameters with potential influence on calculating embodied energy, whereas variations can also be induced from the measurement of building operational energy. Therefore, there is currently a lack of studies adopting a comprehensive approach to seek possible sources of variations throughout the entire process of LCEA analysis while including both operational and embodied energy measurements. To address this gap, the literature relating to the LCEA application in residential buildings has been reviewed with the aim to identify causes of variations in performing LCEA analysis. To this end, we limited the scope of our paper to examining studies published from 2010 onwards. This facilitated the possibility to capture the most up-to-date trends of LCEA application in residential buildings. The identified studies were then analyzed based on their definitions of system boundaries, and methods were applied to estimate embodied energy and operational energy, as well as to interpret the results achieved.

\section{An Overview of Life Cycle Energy Assessment (LCEA)}

The LCA is an approach for identifying and assessing the environmental impacts of products, services, or processes throughout their entire life cycles, namely extracting raw materials, processing and manufacturing, operation, and end-of-life (EOL) [14-18]. The first sets of LCA standards were established during 1997-2000 by the International Organization for Standardization (ISO), leading to the ISO standards 14040, 14041, 14042, and 14043 [19]. In 2006, the updates to these standards were finalized in which the previous versions were amalgamated into ISO 14040 and 14044 [20,21]. The major feature of an ISO standard is a four-step iterative framework, including a goal and scope definition, inventory analysis, life-cycle impact assessment (LCIA), and interpretation (Figure 1).

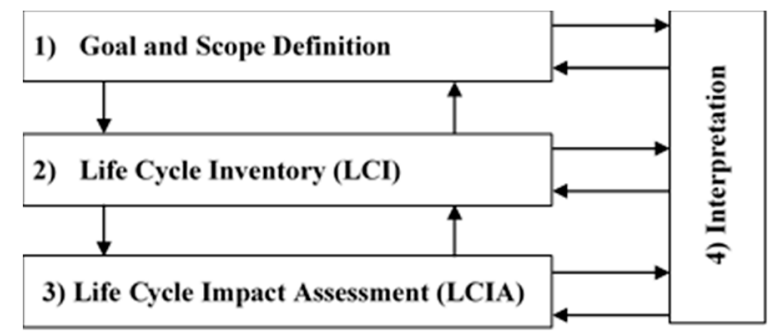

Figure 1. The Life Cycle Assessment (LCA) framework based on International Organization for Standardization (ISO) standard [22].

The first step to perform an LCA analysis is to establish the goals and scope of the study, which encompass defining system boundaries and functional units, as well as determining the quality criteria for inventory data. The life-cycle inventory (LCI) analysis refers to the procedure of collecting data and synthesizing information pertaining to the physical material and energy flows in different stages of the product life cycle. The LCIA is the stage where the environmental impacts of various material and energy flows are quantified and assigned to different environmental impact categories. At the end, the achieved results are finalized for conclusion, recommendation, and decision making purposes. 
The LCEA focuses on the evaluation of energy inputs for different phases of the life cycle [9]. Figure 2 demonstrates the system boundary for performing a whole LCEA study, consisting of raw material extraction, material processing and manufacturing, transportation of materials to the construction site, the process of construction, installation, and erection, building operations and its maintenance, and demolition. The life cycle energy of buildings can be sub-divided into embodied and operational energy.

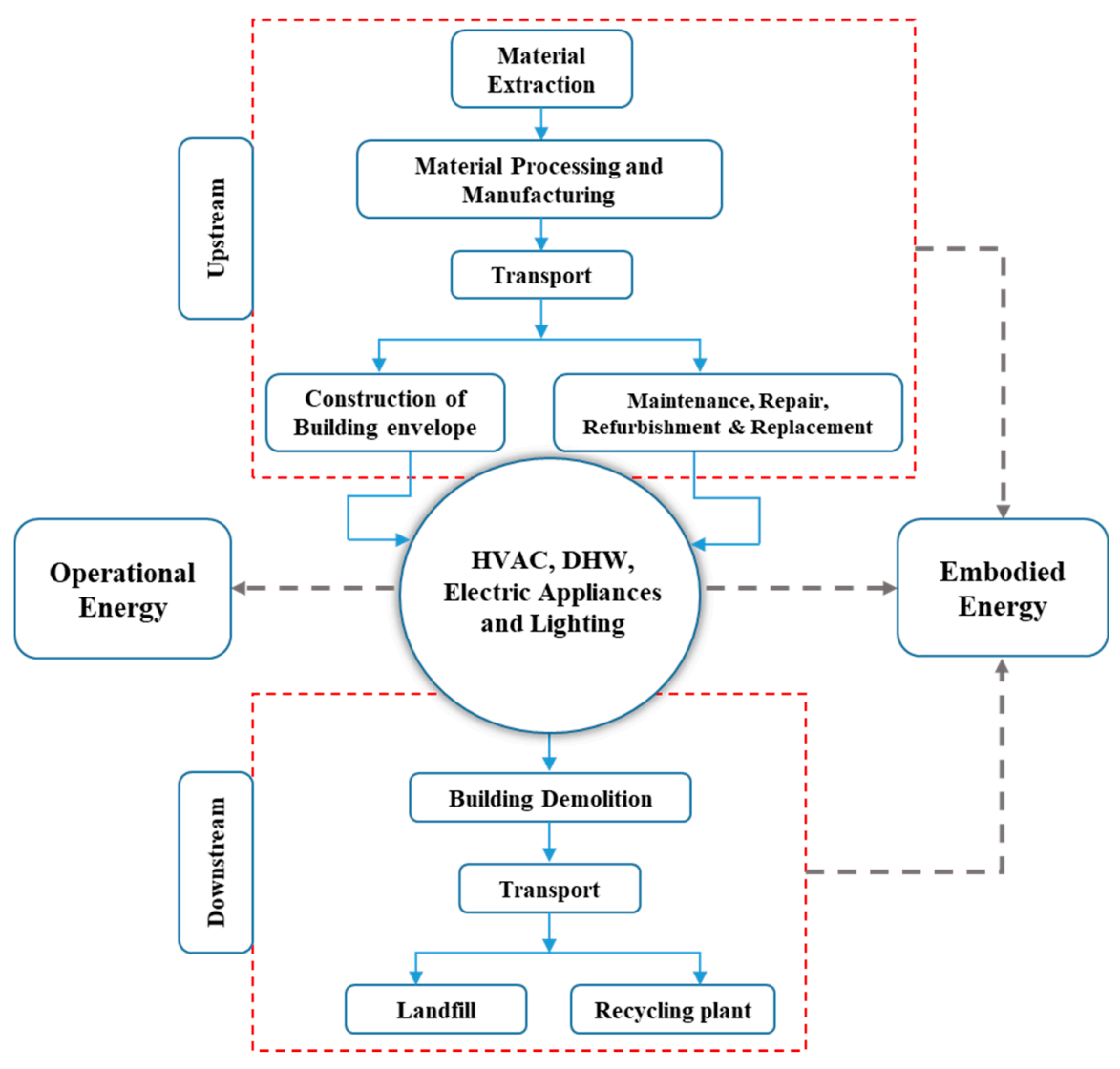

Figure 2. Building life cycle energy (adapted from reference [23]).

Operational energy refers to the amounts of energy consumed in the forms of heating and cooling, domestic hot water (DHW), electrical appliances and equipment, ventilation, lighting, and cooking in order to retain the indoor comfort conditions [24]. The share of operational energy to the total building life cycle energy use is usually higher than the embodied energy [14,23]. As a result, the minimization of this energy has been the focus of many policy-driven schemes developed in different countries to support the construction of energy-efficient buildings.

Embodied energy refers to energy used to extract and refine raw materials, manufacture materials, assemble components, conduct on-site construction, complete EOL processes, and carry out any transportation required between any of these steps [14,15]. Overall, embodied energy can be divided into:

- Initial embodied energy: refers to the quantity of energy incurred for the initial construction of the building including extracting raw materials, processing the extracted materials, and transporting building materials to construction sites and on-site construction and installation.

- Recurring embodied energy: refers to the total amounts of energy embodied in the materials used for maintaining and rehabilitating a building during its life span.

- EOL: refers to the amounts of energy required to demolish the building and to transport the resulted wastages to landfill sites and/or recycling plants. 
The LCEA is, therefore, the sum of embodied energy and operational energy of a building. The reliability of results depends on the completeness and accuracy of the data and the robustness of the methodology applied to carry out an LCEA analysis. The following section elaborates on the research methodology used in this paper.

\section{Materials and Methods}

This paper analyzed instances of the LCEA application in residential buildings using a systematic literature review. The review considered publication materials from various academic databases, namely Scopus, Google Scholar, and Web of Science. The application of multiple search engines to investigate the body of literature covers the weaknesses of one source by using the strength of others $[25,26]$. The approach to conducting the review consists of three main steps.

During the first step, all LCA-related scholarly research publications (more than 300 papers) from 2010 onwards related to the LCA application in residential buildings were identified based on a comprehensive keyword searching exercise (Table 1).

Table 1. Keywords used in the research approach.

\begin{tabular}{c} 
Keywords Applied at the First Stage \\
\hline Life cycle assessment; sustainability assessment; life cycle energy assessment; operational and embodied \\
energy; life cycle environmental assessment; building energy performance; life cycle assessment tools; building \\
energy consumption; building environmental emissions; sustainable construction; life cycle inventory; \\
sustainable building design; building embodied emissions.
\end{tabular}

During the second stage, the titles and abstracts of the identified documents were screened to make an initial judgment about the aptness of the publications for inclusion. Here, the key criteria considered for further analyzing the retrieved materials were (i) the studies must apply LCEA, and (ii) the focus of assessment must be on residential buildings. Also, the studies that were not peer-reviewed or written in English were excluded. In addition, we only accounted for the studies that considered primary energy to perform LCEA analysis. The evaluation of building energy performance can be implemented considering either primary or secondary (delivered) energy. In general, these two cannot be directly compared as they contain different quantities of energy. The energy delivered for end-use contains lower amounts of energy than the actual quantities of primary energy utilized to generate and distribute secondary energy. Thus, the impacts of buildings' life cycle energy use on the built environment can be better represented by using primary energy [11].

During the third stage, the selection process was controlled qualitatively by checking the content of all publication materials in order to ensure that only those corresponding to the scope of this paper were chosen for detailed examination. At this stage, studies with a sole focus on investigating embodied energy were not selected for examination, as they were not holistic in their approaches for appraisal of a building's life cycle energy performance. Analogously, studies with unavailable data on buildings' life cycle energy uses were also excluded from further analysis. It is noteworthy to mention that this survey accounted for all types of residential buildings including conventional and low-energy use buildings (e.g., passive buildings, net zero energy building, nearly zero energy buildings), high-rise buildings, as well as buildings located in rural and urban areas. As a result, 26 papers representing 86 case studies across 12 countries were selected. This paper considers different versions of a similar building investigated in one source, as case studies. The following sections provide a detailed analysis of the case studies.

\section{Analysis and Results}

This section aims to discuss the findings of the reviewed studies. The detailed list of analysis can be found in Appendices A and B (Tables A1 and A2). 


\subsection{System Boundary Definition}

The system boundary refers to a set of variables that delineate the boundary of a particular system and distinguish it from other systems in an environment [12]. The approaches of the reviewed studies to defining system boundaries were analyzed with respect to excluding stage(s) from the building's life cycle, building components considered for embodied energy calculation, parameters considered for operational energy calculations, building life span, and the key assumptions.

\subsubsection{Stages Excluded}

As indicated in Figure 2, the stages of a building life cycle include raw material extraction, material processing and manufacturing, transport, on-site construction and installation, operational phase, and EOL. A whole LCEA study refers to an assessment which accounts for the analysis of energy usage while considering all stages of building life cycle.

The review shows that only $27 \%$ of the studies performed a whole LCEA analysis, while others neglected the impacts of certain stages on total building energy use. It was found that $50 \%$ of the studies excluded the EOL from the system boundaries, which is mainly justified due to its minor contribution to the total building life cycle energy use or the lack of clarity on the deconstruction practices after the end of building life service [5,6,27-35]. Amongst those which considered energy consumption at the EOL, studies usually avoided performing detailed analysis to unveil energy usage at this stage. For instance, Crawford [36] added 1\% of the total building energy demands in order to account for the energy usage at the EOL stage. Similarly, Devi and Palaniappan [37] added an amount equal to $3 \%$ of the total building life cycle energy use to help consider energy usage at the EOL stage. In addition, 'replacement and maintenance' (recurrent embodied energy) has been a subject of exclusion for $27 \%$ of the reviewed studies $[27,31,37-41]$ despite the significant effects that this phase may have on the total building life cycle energy use. Studies reported the recurrent embodied energy may represent up to $31 \%$ of a total building's embodied energy [30]. In another study, Crawford [36] demonstrated the impacts of recurrent embodied energy can constitute up to $22 \%$ of total building life cycle energy demands. Moreover, 'on-site construction', and 'transport' were excluded from system boundaries by $15 \%$ and $4 \%$ of the reviewed studies, respectively.

\subsubsection{Building Components Considered for Measurement of Embodied Energy}

The review shows the studies were inconsistent in accounting for the impacts of embodied energy pertaining to building components and systems (Table 2). From Table 2, it can be understood that there is a consensus on considering embodied energy impacts associated with main building components, namely the building envelope (i.e., external walls, roof, and floor). However, the definition of system boundary differs amongst the reviewed studies concerning inclusion of the impacts of embodied energy related to building systems and installations as well as furniture, appliances, and fixtures. 
Table 2. Different approaches toward the assessment of building embodied energy.

\begin{tabular}{|c|c|c|c|}
\hline Author(s) & Building Components & Furniture/Fixtures/Appliances & Elements Beyond Building Scale \\
\hline Aye et al. [27] & $\begin{array}{l}\text { Columns and beams, external and internal walls, external cladding, ceiling, roof, floor, } \\
\text { doors and windows, floor tiling, staircase. }\end{array}$ & NA & NA \\
\hline Gustavsson et al. [38] & $\begin{array}{l}\text { Foundation, floor structure, roof, external and internal walls, doors and windows, } \\
\text { balconies, stairs. }\end{array}$ & Interior fixtures & NA \\
\hline Dodoo and Gustavsson [42] & $\begin{array}{l}\text { Foundation, floor, roof, external and internal walls, insulation, doors and windows, } \\
\text { balconies, stairs. }\end{array}$ & NA & NA \\
\hline Ramesh et al. [28] & Exterior walls, roof and floor, insulation. & NA & NA \\
\hline Stephan and Stephan [30] & Exterior walls, roof, floor, building structure, insulation, building systems. & NA & Urban infrastructure, occupants' transport \\
\hline Atmaca and Atmaca [43] & $\begin{array}{l}\text { External and internal walls, doors and windows, roof, floor, wall and roof tiles, insulation, } \\
\text { building structure, foundation, façade (plastering, painting). }\end{array}$ & NA & NA \\
\hline Rossi et al. [44] & Basement slab, external and internal walls, roof and floor. & NA & NA \\
\hline Stephan et al. [6] & $\begin{array}{l}\text { Building structure and sub-structure, external and internal walls, finishings, floor, roof, } \\
\text { foundation, systems (piping and wiring), doors and windows, insulations. }\end{array}$ & Carpet, fixtures & Urban infrastructure, occupants' transport \\
\hline Cellura et al. [45] & $\begin{array}{l}\text { Electrical systems, solar thermal system, Photovoltaic (PV) systems, air handling unit, } \\
\text { thermal plant, domestic hot water (DHW) plant, building sub-structure, external and } \\
\text { internal walls, building structure, roof and floor, foundation. }\end{array}$ & NA & NA \\
\hline Stephan et al. [5] & $\begin{array}{l}\text { Building structure and sub-structure, external and internal walls, finishings, floor, roof, } \\
\text { foundation, systems (piping and wiring), doors and windows, insulations. }\end{array}$ & NA & $\begin{array}{l}\text { Urban infrastructure (i.e., roads, power lines, } \\
\text { water and gas distribution, and sewage) }\end{array}$ \\
\hline Crawford [36] & $\begin{array}{l}\text { External walls, roof and floor, doors and windows, paint, building structure, insulation, } \\
\text { foundation. }\end{array}$ & Finishes, appliances, carpet, fitout & NA \\
\hline $\begin{array}{l}\text { Pinky Devi and Palaniappan } \\
\text { [31] }\end{array}$ & $\begin{array}{l}\text { External walls, roof and floor, building structural frames, systems (plumbing, firefighting } \\
\text { and wiring), painting and plastering, foundation. }\end{array}$ & NA & NA \\
\hline Paulsen and Sposto [46] & $\begin{array}{l}\text { External and internal walls, painting and plastering, roof and floor, ceiling, windows, } \\
\text { indoor and external doors. }\end{array}$ & NA & NA \\
\hline Devi and Palaniappan [37] & $\begin{array}{l}\text { Building envelope, structural frames/concreting work, finishing (plastering, painting and } \\
\text { tiling), doors and windows, sanitary installations, systems (plumbing and water pipes) and } \\
\text { steel work (tubes for atrium glazing and stainless steel accessories). }\end{array}$ & NA & NA \\
\hline Bastos et al. [33] & $\begin{array}{l}\begin{array}{l}\text { External and internal walls, floor, roof, staircases, building structures, windows, external } \\
\text { and internal doors. }\end{array} \\
\end{array}$ & NA & NA \\
\hline Ramesh et al. [29] & External walls, roof, widows, PV panels, wind turbine, wiring and installation. & NA & NA \\
\hline Zhan et al. [47] & $\begin{array}{l}\text { External walls, floor, roof, foundation, finishing (plastering, painting and tiling), building } \\
\text { structure. }\end{array}$ & NA & NA \\
\hline Iyer-Raniga and Wong [48] & $\begin{array}{l}\text { Foundations, columns, upper floors, staircases, roof, external and internal walls, windows, } \\
\text { external and internal doors, floor and ceiling finishes. }\end{array}$ & NA & NA \\
\hline Dodoo et al. [39] & $\begin{array}{l}\text { External and internal walls, intermediate floor and ceiling, roof, foundation, windows and } \\
\text { doors, elevator and stair, services and installations, finishes. }\end{array}$ & NA & NA \\
\hline
\end{tabular}


Table 2. Cont.

\begin{tabular}{cccc}
\hline Author(s) & Building Components & Furniture/Fixtures/Appliances & Elements Beyond Building Scale \\
\hline Tettey et al. [40] & Building structure, external and internal walls, floor, insulation and finishes, foundation, & Nindows. & NA \\
\hline Mehta et al. [35] & Building structure, external walls, foundation, roof, floor, and painting. & NA & NA \\
\hline Zhu et al. [41] & External walls, precast façade, staircase, slab, balcony, painting, windows, finishes. & NA \\
\hline Bastos et al. [32] & $\begin{array}{c}\text { External and internal walls, wooden and concrete floors, staircase, roof, windows, } \\
\text { foundations, external and internal doors. }\end{array}$ & NA & NA \\
\hline Goggins et al. [49] & External walls, foundations and floors, roof, chimney, stairs, PV panels, ventilation systems. & Occupants' transport \\
\hline Kristjansdottir et al. [50] & PV system, space-heating system, external and internal walls, foundation, windows and \\
external doors, roof, insulation. & NA \\
\hline Mistretta et al. [51] & $\begin{array}{c}\text { Blinds, electrical system, solar thermal system, PV system, air handling unit, thermal plant, } \\
\text { DHW plant, building frame, external and internal walls, support structures, roof, } \\
\text { foundations. }\end{array}$ & NA & NA \\
\hline
\end{tabular}


Studies also pointed out the possibility of extending their system boundaries to include parameters beyond building elements [5,6,30]. Stephan et al. [5] put forward a framework to account for the impacts of embodied and operational energy of a building while considering the embodied energy of nearby infrastructure (i.e., roads, power lines, water and gas distribution, and sewage) and the transport energy of its occupants. In this framework, they calculated the embodied energy of surrounding infrastructures using process-based hybrid analysis. To do this, the embodied energy of each form of infrastructure was calculated based on the infrastructure density in $\mathrm{m} / \mathrm{km}^{2}$ and attributed to the building based on the population density and the number of users as per Equation (1):

$$
\mathrm{LCEE}_{\text {if }}=\sum_{\mathrm{i}=1}^{\mathrm{I}}\left(\mathrm{LCEE}_{\mathrm{i}} \times \mathrm{D}_{\mathrm{i}} \times \frac{\mathrm{NO}}{\mathrm{PD}}\right)
$$

where LCEE $\mathrm{E}_{\text {if }}$ is the life cycle embodied energy of infrastructure in GJ, LCEEi is the life cycle embodied energy of infrastructure i in GJ/m, $D_{i}$ is the density of infrastructure i in $\mathrm{m} / \mathrm{km}^{2}$, NO is the number of occupants in the building, and PD is population density in inhabitants $/ \mathrm{km}^{2}$. Additionally, they accounted for the energy used as the result of occupants' mobility. They applied this framework to analyze the life cycle energy usage of two buildings located in Australia and Belgium. The results showed the users' transport constituted $25.4 \%$ and $33.8 \%$ of the total building life cycle energy demands in a Belgian passive house and an Australian building, respectively. In another study, Stephan and Stephan [30] estimated the life cycle energy use of a residential building in Lebanon considering the energy embodied in users' transport, including both direct and indirect energy requirements. The direct energy refers to mobility process itself i.e., using fuel in the engine of a car, whereas indirect energy refers to all the processes supporting mobility, such as car registration, insurance, manufacturing the car itself, etc. The life cycle transport energy demand of the building's occupants $\left(\mathrm{LCTE}_{\mathrm{b}}\right)$ was calculated by multiplying the energy intensity of transport modes used in Lebanon (i.e., gasoline cars) by the average traveling distance of occupants using Equation (2):

$$
\mathrm{LCTE}_{\mathrm{b}}=\mathrm{UL}_{\mathrm{b}} \times \sum_{\mathrm{c}=1}^{\mathrm{C}}\left(\mathrm{DCI}_{\mathrm{c}}+\mathrm{IEI}_{\mathrm{c}}\right) \times \mathrm{ATD}_{\mathrm{c}}
$$

where: $\mathrm{LCTE}_{\mathrm{b}}=$ Life cycle transport energy demand of the occupants of building $\mathrm{b}$, in GJ; $\mathrm{UL}_{\mathrm{b}}=$ Useful life of building $\mathrm{b}$, in years; $\mathrm{DEI}_{\mathrm{c}}=$ Direct energy intensity of car $\mathrm{c}$, in $\mathrm{GJ} / \mathrm{km}$; $\mathrm{IEI}_{\mathrm{c}}=$ Indirect energy intensity of car c, in GJ/km; and $\mathrm{ATD}_{\mathrm{c}}=$ Average annual travel distance of car $\mathrm{c}$, in $\mathrm{km}$. The results showed the building life cycle energy demand of the building was dominated by transport energy with a share of $49 \%$, followed by operational and embodied energy with the shares of 33 and $18 \%$, respectively.

From the review, it can be realized that the studies differ according to their approaches for excluding certain stages of building life cycle and measuring embodied energy associated with building components. It was found that the exclusion of building life cycle stages occurs mainly due to the perceived minor impacts of these stages on the total building life cycle energy demand or the uncertainties relating to the fate of building materials at the end of building life. In addition, the reviewed studies were inconsistent in assessing the embodied energy of building components. Although most of the studies only accounted for embodied energy related to building components, the possibility of including embodied energies of parameters such as urban infrastructure or occupants' mobility was also suggested by a number of studies.

\subsubsection{Parameters Considered for Operational Energy Measurement}

The operational energy measurement depends on the extent to which parameters (i.e., heating and cooling, DHW, electrical appliances and equipment, ventilation, lighting, and cooking) are considered for assessment. From the review, it was found that $27 \%$ of the reviewed studies accounted for the 
impacts of all contributors $[5,29,30,32,33,35,36]$. It was also revealed that $62 \%$ of the studies excluded the impacts of cooking on operational energy use, followed by DHW (38\%), electrical appliances $(35 \%)$, lighting $(27 \%)$, and ventilation (23\%). The exclusion of each parameter can influence total building life cycle energy demands by affecting the proportions of operational energy and embodied energy [52,53]. For instance, Gustavsson and Joelsson [52] showed the share of embodied energy in the total building's life cycle energy use was reduced from $33 \%$ to $25 \%$ when the scope of the study was extended from only space heating to including the energy associated with household electricity, DHW, and ventilation.

Although none of the reviewed studies has given justifications, their exclusions can be related to the minor influence that each of these parameters could have on operational energy use.

\subsubsection{Building Life Span}

The life span assumed by the reviewed studies ranged from 50 to 100, with the most commonly used life span of 50 years (Table 3). The assumption of building life span can directly influence the share of both embodied and operational energy. This factor can impact the contribution of embodied energy to the total building life cycle energy consumption by affecting recurrent embodied energy $[54,55]$. The operational energy can also be influenced by the assumption of building life span as the increase of building life span leads to increasing operational energy, whereas assuming a short life span may result in increasing embodied energy over the building's life cycle owing to more frequent substitution of the whole building [56]. In a study, Rauf and Crawford [55] investigated the relation between a building's life span and its embodied energy by using a comprehensive hybrid embodied energy assessment technique. The results unveiled that extending the building's life span from 50 to 150 can result in reducing the life cycle embodied energy demands of the building by $29 \%$.

Table 3. Frequency of building life span.

\begin{tabular}{cc}
\hline Building Life Span & Frequency of Use \\
\hline 50 years & 15 \\
60 years & 2 \\
70 years & 3 \\
75 years & 3 \\
80 years & 1 \\
100 years & $3^{*}$ \\
Total & 27 \\
\hline
\end{tabular}

Note: * Gustavsson et al. [38] considered two life spans: 50 and 100.

\subsubsection{Assumptions}

The assumptions are of the utmost importance in conducting LCEA studies due to their effects on the completeness and accuracy of the achieved results [19]. It was found that the assumptions made by the reviewed studies were associated with different phases of the building life cycle, including the initial, on-site construction, operation, replacement and maintenance, and EOL stages (Table 4). 
Table 4. Overview of the assumptions made by the reviewed studies.

\begin{tabular}{|c|c|c|}
\hline Stage of Building Life Cycle Targeted & Assumption & Reference \\
\hline Operation phase & $\begin{array}{l}\text { The schedule for operating heating and cooling systems is assumed to remain unchanged during the entire course of life } \\
\text { cycle assessment; } \\
\text { The detailed occupational schedules and gains are not considered; } \\
\text { The efficiency of heat pump system is assumed to be constant over time; } \\
\text { The annual operating energy is assumed to remain consistent in throughout the entire building life span; } \\
\text { The effects of climate change and occupants' behaviors in the future are not taken into consideration; } \\
\text { The resource mix supplying electricity to the buildings is assumed to be static; }\end{array}$ & {$[27-29,33,42]$} \\
\hline Initial embodied energy & $\begin{array}{c}\text { Australian database of construction materials is used to calculate the embodied energy; } \\
\text { Australian input-output-based hybrid embodied energy intensities are used for a case study located in Belgium; } \\
\text { Using I-O data relating to production stage that occurred over a decade ago; }\end{array}$ & {$[6,30,36,43,48]$} \\
\hline Embodied energy of on-site construction & $\begin{array}{l}\text { All the manufacturing processes are assumed to be undertaken in one place; } \\
\text { The primary energy used for on-site construction is assumed to be } 80 \mathrm{kWh} / \mathrm{m}^{2} \text {; } \\
\text { The primary energy used for on-site construction is assumed to be } 4 \% \text { of the material production primary energy; } \\
80 \text { and } 160 \mathrm{kWh} / \mathrm{m}^{2} \text { are assumed for the on-site energy consumption of wood and concrete building systems respectively; }\end{array}$ & [38-40] \\
\hline Embodied energy of replacement and refurbishment & $\begin{array}{l}\text { The structural elements of the building are assumed to have the same service life as the house; } \\
\text { The embodied energy associated with replacement, refurbishment and repair of materials and products are assumed to } \\
\text { be } 5 \% \text { every } 10 \text { years; } \\
\text { The replacement lifetimes of construction materials in US are used for LCEA of buildings in Australia; } \\
\text { The standard construction methods and materials are assumed to remain the same during the entire building life span; }\end{array}$ & {$[43,44,48]$} \\
\hline Embodied energy of EOL & $\begin{array}{l}5 \% \text { waste of material is assumed during construction; } \\
\begin{array}{c}90 \% \text { of the wood-based demolition materials are assumed to be recovered while } 10 \% \text { decays into atmosphere; } \\
\text { Only one type of fuel is assumed to be used for transporting the wastages; }\end{array} \\
\text { To account for the contribution of EOL stage, } 1 \% \text { of the total life cycle energy demand is summed to the final achieved } \\
\text { figure; } \\
\text { The embodied energy associated with EOL is assumed to be } 3 \% \text { of the total building life cycle energy demand; } \\
\text { The primary energy use for demolition of wood and concrete are assumed to be } 10 \text { and } 20 \mathrm{kWh} / \mathrm{m}^{2} \text { respectively; } \\
\text { All of the materials are assumed to be landfilled at the EOL stage; } \\
\text { It is assumed that demolition energy will not exceed } 10 \mathrm{kWh} / \mathrm{m}^{2}\end{array}$ & {$[36-40,42,43]$} \\
\hline
\end{tabular}


The first group of assumptions involved the operation stage. It was noted that the estimation of a building's operational energy is commonly carried out for one year, and then the achieved figure has been multiplied by the number of years in which the LCEA study is conducted. Studies assumed that operational energy use would remain unchanged during the entire course of assessment. Although making such an assumption was only declared by a number of authors (as citied in Table 4), it can be mentioned that all the reviewed studies have made a similar assumption. Assuming a constant operational energy consumption implies that the building would have a constant schedule for heating and cooling systems, there would be unchanged patterns of occupancy (e.g., family size or behaviors), or heating and cooling systems would not be subject to depreciation. In another study, Iyer-Raniga and Wong [48] assumed that the resource mix used to supply electricity of the building would be unaltered during 100 years of building operation, despite hefty investments being made globally to promote utilizing renewable energy sources.

The second group contains assumptions related to the estimation of initial embodied energy. Due to the lack of available and reliable data, studies applied databases from other countries in order to calculate embodied energy. For instance, Stephan and Stephan [30] used an Australian database containing embodied energy coefficients for building materials to calculate the embodied energy of a residential building in Lebanon. In another study, Stephan et al. [6] used Australian input-output-based hybrid embodied energy intensities to estimate the embodied energy of a passive building in Belgium. Likewise, Devi and Palaniappan [37] used the Inventory of Carbon and Energy (ICE), which is a database developed in the EU, to estimate the embodied energy of a residential building in India. This assumption may potentially compromise the quality of LCEA results due to inherent differences between the two countries, e.g., different economic sectors (in case of developing input-output matrix) or different construction practices and technologies. The justification given for making such assumptions is commonly related to the absence of a locally developed database.

Assumptions are also made to estimate embodied energy associated with on-site construction, replacement and refurbishment, and EOL stages. Gustavsson et al. [38] assumed primary energy used for on-site construction of an eight-story wood framed apartment is $80 \mathrm{kWh} / \mathrm{m}^{2}$. Dodoo et al. [39] also assumed that on-site construction embodied energy is equivalent to $4 \%$ of the material production primary energy. As shown in Table 4, assumptions were made on replacement and refurbishment of the buildings. Atmaca and Atmaca [43] assumed that the standard construction methods and practices would be unchanged during the entire building life span. The substitution of building materials during the use phase of the building with the exact same material is another assumption, which is not commonly specified but has been utilized by the majority of the LCEA studies. For this assumption, construction materials would be replaced by similar materials with the same energy intensities. Regarding to the EOL stage, studies assumed different shares of energy consumptions $[36,37,39]$. For instance, Devi and Palaniappan [37] assumed that this stage consumes 3\% of the total building life cycle energy demand. Dodoo et al. [39] also assumed the demolition at the EOL stage would not exceed $10 \mathrm{kWh} / \mathrm{m}^{2}$.

The majority of these assumptions were made to mitigate the complexity involved in embodied energy calculation or due to the lack of reliable data. Considering the potential impacts of assumptions on results, it can be recommended for LCEA studies to clearly mention assumptions while justifying their contextual applicability and appropriateness. Moreover, assessing the impacts of each assumption on the LCEA results could be an interesting topic for future research.

\subsection{The Assessment of Embodied Energy}

The embodied energy assessment commences with obtaining qualitative and quantitative data for each unit process that will be included within the system boundaries. For buildings, these data are collected by investigating technical specifications or drawings of buildings, site surveys or using contractor records. A similar approach was undertaken by the reviewed studies to collect the required 
data. For instance, Gustavsson et al. [38] used construction drawings and personal communication with staff of the construction industries to obtain the total quantities of building materials.

Once the required data are collected, the method to quantify embodied energy needs to be determined. Three major approaches are commonly used for the calculation of embodied energy, including the process-based approach, economic input-output (I-O) approach, and input-output-based hybrid approach. The process-based is a traditional approach, which is preferred when the physical flow of goods and services can be easily identified and traced. However, this method may become overwhelmingly complicated when inputs and outputs are numerous [43]. Moreover, it is prone to errors induced by the subjective removal of the iterative effect from the upstream production system [41]. Alternatively, the economic I-O approach follows a top-down approach and treats the whole economy as the boundary of analysis in order to arrive at consistent boundary definitions between studies. The economic I-O is based on the flow of materials in an economic structure aiming to determine the amount of primary energy required to produce a specific product or service. Although the application of this approach rectifies the incompleteness of the system boundary for capturing the upstream effects, it still lacks product-specific data. Hence, an I-O based hybrid approach was proposed to combine both process-based and economic I-O approaches and therefore cover the inputs from the entire upstream supply chain [57].

From the review, it was found that $62 \%$ of the reviewed studies applied the process-based approach to assess embodied energy, while $27 \%$ utilized the I-O based hybrid approach. Furthermore, $11 \%$ of the reviewed studies did not discuss their approaches for measurement of embodied energy. The magnitude of estimates achieved by the reviewed studies for embodied energy largely depends on the approach used for the calculation of this energy. Studies with the I-O based hybrid approach were more likely to obtain a high value for embodied energy since this approach captures energy usage embedded in both upstream and downstream stages of the building life cycle [7,30,57].

To calculate embodied energy associated with building materials, a background database containing datasets that represent technical and economic context must be selected. From the review, it was found the required background data were retrieved from two primary sources: 'literature', and publicly or commercially available databases (Table 5). The 'literature' refers to the embodied energy coefficients of previously published LCEA studies. Overall, $19 \%$ of the reviewed studies solely relied on the literature for calculating embodied energy. The mere reliance on literature may potentially compromise the quality of the achieved results, since the background databases are not representative of the building's regional contexts (construction technology, climatic conditions, etc.).

Table 5. Databases applied by reviewed studies.

\begin{tabular}{|c|c|c|c|c|c|}
\hline Database & Developer & Data Coverage & Access & Boundary & LCI Method \\
\hline SimaPro & $\begin{array}{l}\text { PRe' Consultants, } \\
\text { Netherlands }\end{array}$ & $\begin{array}{c}\text { Ecoinvent, US LCI, Danish } \\
\text { input-output database, Dutch } \\
\text { input-output database, LCA food } \\
\text { database, Industry data }\end{array}$ & Licensed access & Cradle-to-grave & $\begin{array}{l}\text { Process- based } \\
\text { and I-O method }\end{array}$ \\
\hline Ecoinvent & Ecoinvent centre, Swiss & $\begin{array}{l}\text { General products and processes } \\
\text { including energy, transport, building } \\
\text { materials, chemicals, washing agents, } \\
\text { paper and board, agriculture, waste } \\
\text { management, International data }\end{array}$ & Licensed access & Cradle-to-gate & $\begin{array}{l}\text { Process-based } \\
\text { method }\end{array}$ \\
\hline ICE & Bath University, UK & $\begin{array}{l}\text { Construction and building materials, } \\
\text { EU, mostly UK data }\end{array}$ & $\begin{array}{l}\text { Publicly } \\
\text { available }\end{array}$ & Cradle-to-gate & $\begin{array}{l}\text { Process-based } \\
\text { method }\end{array}$ \\
\hline AusLCI & $\begin{array}{l}\text { Building Product Innovation } \\
\text { Council, Australia }\end{array}$ & $\begin{array}{l}\text { Building and construction materials } \\
\text { and products, Building product } \\
\text { maintenance and replacement life } \\
\text { data, Australian data }\end{array}$ & $\begin{array}{l}\text { Publicly } \\
\text { available }\end{array}$ & Cradle-to-grave & $\begin{array}{l}\text { Process-based } \\
\text { method }\end{array}$ \\
\hline BEES & $\begin{array}{l}\text { National Institute of } \\
\text { Standards and Technology } \\
\text { (U.S.) }\end{array}$ & $\begin{array}{l}\text { Construction and building materials, } \\
\text { mostly U.S. data }\end{array}$ & $\begin{array}{l}\text { Publicly } \\
\text { available }\end{array}$ & Cradle-to-grave & $\begin{array}{l}\text { Process-based } \\
\text { method }\end{array}$ \\
\hline $\begin{array}{l}\text { Database of Embodied } \\
\text { Energy and Water Values } \\
\text { for Materials }\end{array}$ & $\begin{array}{l}\text { The University of } \\
\text { Melbourne }\end{array}$ & $\begin{array}{c}\text { Construction and building materials, } \\
\text { Australian data }\end{array}$ & $\begin{array}{l}\text { Publicly } \\
\text { available }\end{array}$ & Cradle-to-grave & $\begin{array}{c}\text { I-O based } \\
\text { hybrid method }\end{array}$ \\
\hline CLCD & $\begin{array}{l}\text { Sichuan University, China; } \\
\text { IKE Environmental } \\
\text { Technology CO., Ltd., China }\end{array}$ & $\begin{array}{l}\text { Materials and chemicals, energy } \\
\text { carriers, transport, and waste } \\
\text { management, China }\end{array}$ & $\begin{array}{l}\text { Publicly } \\
\text { available }\end{array}$ & Cradle-to-gate & $\begin{array}{l}\text { Process-based } \\
\text { method }\end{array}$ \\
\hline
\end{tabular}


In addition, several databases including both process-based and I-O based hybrid databases were employed for calculation of buildings' embodied energy (Table 5). The findings indicate that $50 \%$ of the studies used generic international databases, namely ICE, Building for Environmental and Economic Sustainability (BEES), SimaPro, and Ecoinvent. Other process-based databases such as the Chinese Life Cycle Database (CLCD) and Australian National Life Cycle Inventory Database (AusLCI) were also used by the reviewed studies to acquire process specific data in order to form I-O hybrid databases $[27,30,36,41]$.

From the review, it became evident that the studies differ significantly with respect to their approaches for calculating buildings' embodied energy. These variations stem from different types of methods and databases applied by the reviewed studies to assess buildings' embodied energy, combined with excluding a stage(s) of building life span, considering embodied energies associated with different building components, assuming different building life spans, and various assumptions attributing values to embodied energy calculations.

\subsection{The Assessment of Operational Energy}

Operational energy is commonly known for having the highest share of energy consumption in a building's life cycle [14,23]. Although previous studies attempted to draw a solid conclusion of a building's operational energy by juxtaposing different case studies $[9,14,23,58-60]$, cross-comparison cannot be implemented in reality due to the varying approaches of studies for measuring operational energy. As previously mentioned, system boundary definition is a critical factor in calculating operational energy, as it involves including parameters with a potential influence on how operational energy use is determined. In addition, methods applied to calculate buildings' operational energy is another important variable leading to variations in LCEA results. Based on the review, methods utilized by the studies to calculate buildings' operational energy usage are categorized into four groups:

- Using the actual records of building energy usage collected from utility bills, or energy audit exercises. The review found that $12 \%$ of the studies used this method to calculate the operational energy. Using this approach enables researchers to take into consideration all types of energy consumed in buildings including heating, cooling, lighting, DHW, cooking, and appliances. For instance, Atmaca and Atmaca [43] and Mehta et al. [35] used energy bills to estimate building operational energy use. Employing this method provides the ability to capture the dynamics of occupants' behaviors on energy consumption within a year. However, the application of this method can only supply an aggregated figure of building energy consumption, while failing to present a detailed breakdown of energy by use. This would potentially prevent decision makers from identifying the hot spots of energy consumption in building and providing solutions for energy reduction.

- Using energy simulation software. It was found that $44 \%$ of the reviewed studies applied simulation software packages to estimate optional energy use. These software packages are commonly capable of producing detailed data on the annual energy consumption of buildings. Although the application of simulation software may ease the process of estimating operational energy, the accuracy of results achieved via simulation software can still be improved. One way to approach this challenge is to calibrate the simulation model to fit the real energy performance of the existing building. In addition, the impacts of users' behaviors on energy usage can be better taken into consideration. The two possible approaches to better account for the impacts of users' behaviors on energy use in buildings are deterministic and stochastic statistical approaches [61]. The deterministic approach refers to defining different scenarios for users' behaviors ranging from 'energy saving' to 'wasteful' behavior scenarios in respect to using energy in building e.g., DHW, on an hourly basis throughout the year. In addition, sensitivity analysis can be applied for the same purpose where sufficient data on users' behaviors are unavailable. Alternatively, the stochastic statistical model can be used to predict the users' attendance and activity in the 
building for inclusion into a simulation. In this model, relevant data should be collected through literature and national sociological investigations.

- Static equations. Another method used by the reviewed studies (22\%) for estimating operational energy was static equations $[5,6,30,46,47]$. In a study, Stephan et al. [5] estimated the operational energy of a residential building using Equation (3):

$$
\mathrm{LCOPE}_{\mathrm{b}}=\mathrm{UL}_{\mathrm{b}} \times \sum_{\mathrm{e}=1}^{\mathrm{E}}\left(1-\mathrm{SF}_{\mathrm{e}}\right) \times \frac{\mathrm{OPE}_{\mathrm{e}}}{\mathrm{n}_{\mathrm{e}}}
$$

where $\mathrm{LCOPE}_{\mathrm{b}}$ is the life cycle primary operational energy of the building $\mathrm{b}$ in GJ, $\mathrm{UL}_{\mathrm{b}}$ is the useful life of the building $\mathrm{b}, \mathrm{SF}_{\mathrm{e}}$ is the solar fraction for the end-use $\mathrm{e}, \mathrm{OPE}_{\mathrm{e}}$ is the yearly operational final energy demand of the end-use e in GJ, and neis the average efficiency of the end-use e. The annual operational energy uses for heating and cooling were estimated by applying Equation (4):

$$
\mathrm{OPE}_{\mathrm{h}}=\mathrm{HDH} \times\left[\mathrm{U}_{\mathrm{b}} \times \mathrm{A}_{\mathrm{ht}}+\left(1-\eta_{\mathrm{HR}}\right) \times \mathrm{SV}_{\mathrm{ht}}\right)
$$

where $\mathrm{OPE}_{\mathrm{h}}$ is the operational final heating energy demand in $\mathrm{kWh}, \mathrm{HDH}$ is the thousands of heating degree hours for the building site in $\mathrm{Kh}, \mathrm{U}_{\mathrm{b}}$ is the average heat transfer coefficient for the building in $\mathrm{W} /\left(\mathrm{m}^{2} \mathrm{~K}\right), \mathrm{A}_{\mathrm{ht}}$ is the area of heat transfer in $\mathrm{m}^{2}, \eta \mathrm{HR}$ is the efficiency of the heat recovery system if present, and $\mathrm{V}_{\mathrm{ht}}$ is the ventilation heat transfer in $\mathrm{W} / \mathrm{K}$. The cooling energy demand was also calculated using Equation (4) by substituting the cooling degree hours for the heating degree hours. The ventilation energy demand was achieved by using Equation (5):

$$
\mathrm{OPEv}=\mathrm{V} \times \mathrm{H} \times \mathrm{P}
$$

where OPEv is the operational final ventilation energy in $\mathrm{kWh}, \mathrm{V}$ is the ventilated volume in $\mathrm{m} 3$, $\mathrm{H}$ is the thousands of hours of mechanical ventilation per year, and $\mathrm{P}$ is the average fan power in $\mathrm{W} / \mathrm{m}^{3}$. The energy demands for DHW, appliances, and cooking were determined by multiplying regional per capita averages by the number of users in the house. Lighting was calculated by multiplying average annual energy usage per $\mathrm{m}^{2}$ by the usable floor area of the building. The average regional energy consumption data were then gained by using records published by governmental bodies. The final energy demands achieved were converted into primary energy applying appropriate conversion factors. Equation (3) also accounted for situations where solar systems are installed. In this case, solar fractions should be deduced from the final energy consumption of related end-uses. However, using this method can be time-consuming once the aim is to optimize a building design through parametric analysis. In addition, this method fails to capture buildings' thermal history when calculating cooling and heating loads e.g., time delay between heat absorptance and heat release by enclosing components of a room.

- Miscellaneous. Other methods have been also used by the reviewed studies for calculating operational energy. For instance, Cellura et al. [45] monitored the annual energy consumption of a building in order to have an accurate estimate of the building operational energy use. Similarly, Devi and Palaniappan [37] monitored buildings' energy consumption for 21 months and then used the data for estimation of operational energy. In another study, Bastos et al. [32,33] estimated the operational energy consumptions while considering the ratio between residential electricity use and natural gas or LPG provided by the Lisbon Energy Matrix, which provides estimates of energy use in Lisbon building stock using 2002 data.

Similar to embodied energy, the approaches for calculation of operational energy also differed across the reviewed studies in two major aspects; (i) accounting for the impacts of parameters contributing to operational energy use and (ii) the approaches applied for calculation of operational 
energy use. The varied approaches for calculations of both embodied energy and operational energy may significantly influence the accuracy and completeness of the results reported by LCEA studies.

\subsection{Interpretation}

The final stage of an LCEA study is 'interpretation' in which the results of the analyses are discussed and recommendations are accordingly given. The interpretation of each LCEA study is unique, corresponding to the particular goal and defined system boundaries. The ISO 14044 recommends performing different types of 'evaluations' including a completeness check, sensitivity check, and consistency check in order to provide assurance of the robustness of the achieved results [20]. The completeness check refers to the process in which the completeness of all relevant information and data required for the interpretation is checked. The sensitivity analysis means that the reliability of the results and conclusions should be checked by determining how they are affected by uncertainties in the data, allocation methods, calculations of category indicator results, etc. The consistency check refers to the process in which the assumptions, methods, and data should be checked for whether they are consistent with the goal and scope of the study.

From the review, it was realized that three methods were commonly utilized by the reviewed studies as a means of 'evaluation': sensitivity analysis, uncertainty analysis, and discussion of limitations. In regards to sensitivity analysis, $31 \%$ of the studies applied this method to test the influence of inventory data parameters. For instance, Rossi et al. [44] assessed the impacts of climate and the energy mix on total building life cycle energy demands. Dodoo et al. [39] also tested the influence of insulation choices, building life span, air infiltration rates, and ventilation heat recovery (VHR) efficiency. The building life service is another parameter which has been subject to sensitivity analysis by studies [37,48]. Pinky Devi and Palaniappan [31] considered the influence of service life and efficiency in building operations on the total building life cycle energy use. Regarding the uncertainty analysis, 19\% of the reviewed studies used this method. Gustavsson et al. [38] performed a qualitative uncertainty analysis, while Stephan and Stephan [30], Stephan et al. [5], and Stephan et al. [6] used the interval analysis method to quantitatively compute the uncertainty in embodied energy figures. Finally, 31\% of the reviewed studies discussed the inherent limitations involving their research. Overall, no study performed all of the aforementioned evaluation methods, five studies included two of them $[30,31,44,48,50]$, and ten studies did not consider performing any evaluation [27-29,41,42,45-47,49,51].

In addition to ISO 14044's recommendation of a number of evaluations in order to assure the quality of results, other standards and guidelines have suggested certain measures to be taken at the interpretation stage. The EN 15978 introduced some rules to maintain the quality of final research, namely involving data validation [61]. Furthermore, EeBGuide recommends carrying out an uncertainty analysis, and where it is relevant, modeling an alternative scenario for each life cycle stage of a building [61].

\subsection{Reuse and Recycling Potentials}

The reuse and recycling potential refers to the process in which the benefits and loads from materials and energy beyond the assessed building's system boundary are captured [61]. It was found that eight studies considered processes associated with recycling potentials of building materials $[27,38-40,42,45,49,51]$. They considered reusing materials such as biomass residues during the production stage $[47-49,55]$ and on the construction site [39] as well as recycling building materials such as concrete, steel, and wood at the EOL stage [47-49,55]. Table 6 shows the amounts of energy saved at the production, construction, and EOL stages of a building life cycle, along with representing the percentage of energy saved throughout the entire building life cycle by recycling or reusing materials (detailed data on energy saving were available for five studies). 
Table 6. The reuse, recovery, and recycling potential for reducing total building life cycle energy use across the building life cycle $\left(\mathrm{kWh} / \mathrm{m}^{2}\right.$.annuam).

\begin{tabular}{|c|c|c|c|c|c|c|}
\hline Reference & $\begin{array}{l}\text { Case Study } \\
\text { ID }\end{array}$ & $\begin{array}{l}\text { Energy Recovered } \\
\text { at Production Stage }\end{array}$ & $\begin{array}{l}\text { Energy Recovered at } \\
\text { Construction Stage }\end{array}$ & $\begin{array}{l}\text { Energy Recovered } \\
\text { at EOL Stage }\end{array}$ & $\begin{array}{l}\text { Total Energy } \\
\text { Recovered }\end{array}$ & $\begin{array}{c}\text { Total Energy } \\
\text { Saved (\%) }\end{array}$ \\
\hline $\begin{array}{c}\text { Gustavsson et al. } \\
{[38]}\end{array}$ & CS 4 & 23.64 & NA & 11.42 & 35.06 & 17.84 \\
\hline \multirow{6}{*}{$\begin{array}{c}\text { Dodoo and } \\
\text { Gustavsson [42] }\end{array}$} & CS 5 & 7.78 & NA & 7.92 & 15.70 & 5.36 \\
\hline & CS 6 & 7.78 & NA & 7.92 & 15.70 & 7.27 \\
\hline & CS 7 & 7.78 & NA & 7.92 & 15.70 & 7.79 \\
\hline & $\operatorname{CS} 8$ & 8.0 & NA & 8.06 & 16.06 & 6.05 \\
\hline & CS 9 & 8.0 & NA & 8.06 & 16.06 & 7.77 \\
\hline & CS10 & 8.0 & NA & 8.06 & 16.06 & 8.22 \\
\hline Cellura et al. [45] & CS23 & NA & NA & 19.01 & 19.01 & 9.14 \\
\hline \multirow{6}{*}{ Dodoo et al. [39] } & CS 62 & 20.92 & 1.44 & 11.80 & 34.16 & 15.70 \\
\hline & CS 63 & 20.22 & 1.26 & 10.90 & 32.38 & 9.54 \\
\hline & CS 64 & 10.18 & 1.10 & 9.04 & 20.32 & 9.04 \\
\hline & CS 65 & 20.92 & 1.44 & 11.80 & 34.16 & 14.88 \\
\hline & CS 66 & 20.22 & 1.26 & 10.90 & 32.38 & 15.02 \\
\hline & CS 67 & 10.18 & 1.10 & 9.04 & 20.32 & 9.54 \\
\hline \multirow{5}{*}{ Tettey et al. [40] } & CS 68 & 1.92 & NA & 5.63 & 7.55 & 4.90 \\
\hline & CS 69 & 20.98 & NA & 10.67 & 31.65 & 21.24 \\
\hline & CS 70 & 8.075 & NA & 6.30 & 14.38 & 9.75 \\
\hline & CS 71 & 1.92 & NA & 5.63 & 7.55 & 8.55 \\
\hline & CS 72 & 8.53 & NA & 6.57 & 15.10 & 18.37 \\
\hline
\end{tabular}

Reusing and recycling building materials has already been suggested as an effective strategy to mitigate energy use in the building life cycle by decreasing embodied energy $[8,62]$. Based on Table 6 , it can be observed that this strategy led to the reduction of total building life cycle energy use by the range of $5 \%$ to $22 \%$.

\section{Methodological Challenges}

The overall methodological trends of the reviewed studies are shown in Table 7. As indicated, the present application of LCEA in residential buildings suffers from 'incompleteness' in defining system boundaries, and has 'ambiguity' in terms of measuring embodied energy and operational energy. Regarding 'incompleteness', it was realized the majority of the reviewed studies tended to exclude certain stages of the building life cycle from system boundaries. The impacts of energy consumed at the EOL were commonly discounted, with the reasoning that this stage may contribute negligibly to the total life cycle energy use of buildings. This approach not only leads to truncating system boundaries, but also deprives studies of the beneficial potential of reusing or recycling building materials at this stage.

Table 7. Overall trends of methodological aspects compiled from the reviewed studies.

\begin{tabular}{|c|c|}
\hline Methodological Aspects & Overall Trends of Reviewed Studies for LCEA Application \\
\hline Stages of building life cycle excluded & $\begin{array}{l}50 \% \text { excluded EOL; } 27 \% \text { replacement and maintenance; } 15 \% \text { excluded on-site } \\
\text { construction; } 4 \% \text { excluded transport. }\end{array}$ \\
\hline Elements proposed for inclusion within system boundary & $\begin{array}{l}\text { Three studies accounted for the inclusion of user's mobility over building life cycle; } \\
\text { three studies accounted for the embodied energy of infrastructure on which } \\
\text { buildings rely for receiving energy. }\end{array}$ \\
\hline Building life span & $58 \%$ of the reviewed studies considered 50 years as the life span. \\
\hline Assumptions & All stages have been subject to assumptions. \\
\hline Reuse, recovery and recycling potential & $31 \%$ of the reviewed studies considered recycling and reusing building materials. \\
\hline The approach used for quantification of embodied energy & $62 \%$ used process-based approach and $27 \%$ applied I-O based hybrid approach. \\
\hline Database applied for estimating embodied energy & $\begin{array}{l}50 \% \text { used generic international databases; } 19 \% \text { relied on the literature to retrieve } \\
\text { embodied energy coefficients. }\end{array}$ \\
\hline Contributors considered when estimating operational energy & $\begin{array}{l}62 \% \text { excluded cooking; } 38 \% \text { excluded DHW; } 35 \% \text { excluded electrical appliances; } \\
27 \% \text { excluded lighting; and } 23 \% \text { excluded ventilation. }\end{array}$ \\
\hline
\end{tabular}


Table 7. Cont.

\begin{tabular}{cr}
\hline Methodological Aspects & Overall Trends of Reviewed Studies for LCEA Application \\
\hline Methods used for estimation of operational energy & $\begin{array}{c}44 \% \text { used software; 22\% used static equations; } 12 \% \text { used energy bills. Other } \\
\text { methods were also used such as monitoring energy consumption and using the } \\
\text { national average of energy use for building stock. }\end{array}$ \\
\hline Interpretation & $\begin{array}{c}31 \% \text { used sensitivity analysis; } 19 \% \text { used uncertainty analysis; } 31 \% \text { discussed the } \\
\text { limitations of these approaches. 19\% used two methods. }\end{array}$ \\
\hline Geographical context & $50 \%$ focused on Europe; 31\% on Asia; $15 \%$ on Australia; $4 \%$ on South America. \\
\hline
\end{tabular}

Furthermore, the extent of the inclusion of embodied energy impacts associated with building components and systems was unclear. Some studies limited their scopes of assessment to analyzing building elements (e.g., the building envelope) while there were studies which endeavored to include the embodied energy of urban infrastructure and occupants' mobility within the system boundaries. Likewise, the extent of the inclusion of parameters contributing to buildings' operational energy use varied across the reviewed studies. Only seven studies accounted for all of the parameters $[5,29,30,32,33,35,36]$, whereas others excluded the impacts of a number of parameters. The lack of consensus on measurements of operational and embodied energies was also noted among the reviewed studies. The diversity in methods applied for calculating embodied and operational energies can affect the completeness and accuracy of the LCEA results while limiting cross comparability of the analyzed case studies. Apart from technical characteristics of LCEA analysis, the difference in geographic contexts of the reviewed studies was another source of variation in aspects of climatic conditions, quality of raw materials, production processes, economic data, processes of delivered energy generation, transport distances, energy use (fuel) in transport, and labor [10].

Despite the promising outlook of LCEA applications, the current state of this research area is plagued by inaccuracies accruing from incomplete definitions of system boundaries, coupled with ambiguous approaches for calculating embodied and operational energies. Hence, the process of decision-making can be affected due to inaccurate and incomplete results reported by LCEA studies. The inaccurate results can also influence the successful implementation of environmental practices, namely eco-labeling, through which users are informed about the environmental characteristics of buildings. Furthermore, the inconsistencies shown in Table 7 that exist throughout the entire process of LCEA analysis makes cross-comparison of the case studies impossible. Cross-comparison is important in developing an advanced knowledge about LCEA applications in residential buildings within a global context.

The diversity in applying LCEA signifies the necessity of developing a framework to standardize system boundaries, while providing guidelines on the measurements of operational and embodied energies. Previous studies endorsed a similar need to develop a standardized framework for the measurement of buildings' embodied energy [13]. However, the findings of this study showed that variations could also be induced from the measurement of operational energy. Therefore, there is a need to develop a much comprehensive framework to account for the buildings' environmental impacts, which would consider both embodied and operational energies.

\section{Conclusions}

This paper reviewed the current trend of LCEA application in residential buildings using a systematic literature review. Notwithstanding the extensiveness of the collected data and synthetic process of analyzing their embedded information relevant to the study's objectives, a number of limitations can be highlighted. First, the process of data collection and content analysis has been limited to the search engines, databases, and applied research terms. Moreover, the scope of the paper was limited to analyzing materials published from 2010 onwards, aiming to obtain an up-to-date understanding the use of LCEA for residential buildings. Despite the highlighted limitations, this paper managed to identify 26 papers representing 86 case studies across 12 countries. The analysis of the case studies enabled this paper to capture the most recent trends of utilizing LCEA for residential buildings. 
The review shows the LCEA application for residential buildings is yet to be fully-fledged in providing accurate and complete results for decision-making purposes. This review shows the current trend of utilizing LCEA is suffering from an incomplete definition of system boundaries, combined with the ambiguous approaches for calculating embodied and operational energies. These limitations can further lead to affecting the process of decision-making while limiting the cross-comparability of the case studies. The necessity of developing a framework for standardization of system boundary definition in embodied energy measurement has been already highlighted by previous studies [13]. The findings of this study call for a comprehensive framework in which system boundary definitions for assessments of both embodied energy and operational energy can be standardized, while providing guidelines on methods for measuring these energies.

\section{Future Study}

This paper is a part of an ongoing project that aims to develop a conceptual framework to which the energy consumption of residential buildings throughout their entire building life cycles can be taken into consideration in a systematic and comparable approach. The next step for this research is to develop the framework based on the findings of this paper, and then validate its feasibility by assessing case studies.

Author Contributions: Data collection and analysis, H.O.; Methodology, H.O. and V.S.; Supervision, V.S.; Validation, H.O. and V.S.; Writing—original draft, H.O.; Writing—review \& editing, V.S., E.S. and A.S. All authors have read and agreed to the published version of the manuscript.

Funding: This research received no external funding.

Conflicts of Interest: The authors declare no conflict of interest. 


\section{Appendix A}

Table A1. Studies utilized LCEA in residential buildings.

\begin{tabular}{|c|c|c|c|c|c|c|c|c|c|}
\hline \multirow{2}{*}{ Authors } & \multirow{2}{*}{ Country } & \multirow{2}{*}{$\operatorname{Size}\left(M^{2}\right)$} & \multicolumn{4}{|c|}{ System Boundary } & \multirow{2}{*}{ LCI } & \multirow{2}{*}{ LCIA } & \multirow{2}{*}{ Interpretatio } \\
\hline & & & Stage(s) Excluded & $\begin{array}{c}\text { Life Span } \\
\text { (Yrs) }\end{array}$ & Operational Energy & Assumptions & & & \\
\hline Aye et al. [27] & Australia & 3943 & $\begin{array}{l}\text { EOL and replacement } \\
\quad \& \text { maintenance }\end{array}$ & 50 & Heating and cooling & $\begin{array}{l}\text { The schedule for operating heating } \\
\text { and cooling systems is assumed } \\
\text { constant; The detailed } \\
\text { occupational schedules and gains } \\
\text { are not considered; The efficiency } \\
\text { of heat pump system is assumed to } \\
\text { consistent over time. }\end{array}$ & $\begin{array}{l}\text { Input-output-based hybrid } \\
\text { approach is used; } \\
\text { Input-output data is taken } \\
\text { from the Australian National } \\
\text { Accounts, combined with } \\
\text { energy intensity factors by fuel } \\
\text { type, Processs specific data are } \\
\text { retrieved from SimaPro } \\
\text { Australian database }\end{array}$ & $\begin{array}{l}\text { TRNSYS simulation software is } \\
\text { used to estimate the building } \\
\text { operational energy; } \\
\text { The materials' quantities are } \\
\text { multiplied by their respective } \\
\text { embodied energy intensities, } \\
\text { and summed. }\end{array}$ & None \\
\hline $\begin{array}{c}\text { Gustavsson et al. } \\
\text { [38] }\end{array}$ & Sweden & 3374 & $\begin{array}{l}\text { Replacement \& } \\
\text { maintenance }\end{array}$ & 50 and 100 & $\begin{array}{c}\text { Heating, DHW, household } \\
\text { electricity, and electricity } \\
\text { for facility management } \\
\text { purposes. }\end{array}$ & $\begin{array}{l}\text { The primary energy used for } \\
\text { on-site construction is assumed } 80 \\
\mathrm{kWh} / \mathrm{m}^{2} ; 5 \% \text { waste of material is } \\
\text { assumed during construction; } 90 \% \\
\text { of the wood-based demolition } \\
\text { materials are assumed to be } \\
\text { recovered. }\end{array}$ & $\begin{array}{l}\text { Process-based approach is } \\
\text { used; } \\
\text { Detailed info acquired from the } \\
\text { manufacturers of building } \\
\text { materials; } \\
\begin{array}{c}\text { Literature is used to obtain } \\
\text { required embodied energy } \\
\text { intensities of building } \\
\text { materials }\end{array} \\
\end{array}$ & $\begin{array}{l}\text { ENORM and ENSYST software } \\
\text { are used to estimate the } \\
\text { operational energy; } \\
\text { The materials' quantities are } \\
\text { multiplied by their respective } \\
\text { embodied energy intensities, } \\
\text { and summed }\end{array}$ & UA \\
\hline $\begin{array}{l}\text { Dodoo and } \\
\text { Gustavsson [42] }\end{array}$ & Sweden & 1190 & None & 50 & $\begin{array}{l}\text { Heating, DHW, electricity } \\
\text { for ventilation fans and } \\
\text { pump, and electricity for } \\
\text { household. }\end{array}$ & $\begin{array}{l}\text { The efficiency of heating systems is } \\
\text { assumed to be } 85 \% \text { and consistent } \\
\text { throughout the entire building life } \\
\text { span; } \\
\text { It is assumed that } 90 \% \text { of concrete, } \\
\text { wood and steel materials would be } \\
\text { recovered at EOL. }\end{array}$ & $\begin{array}{l}\text { Process-based approach is } \\
\text { used; } \\
\text { Literature is used for obtaining } \\
\text { primary data on embodied } \\
\text { energy. }\end{array}$ & $\begin{array}{l}\text { VIP + software is used to } \\
\text { estimate the operational } \\
\text { energy; } \\
\text { ENSYST is used to calculate } \\
\text { the final energy for the } \\
\text { operation activities; } \\
\text { The embodied energy } \\
\text { calculation is carried out } \\
\text { multiplying the unit values by } \\
\text { the area of each building } \\
\text { element. }\end{array}$ & None \\
\hline Ramesh et al. [28] & India & 85.5 & $\begin{array}{c}\text { Construction and } \\
\text { EOL }\end{array}$ & 75 & $\begin{array}{l}\text { Heating, cooling, DHW, } \\
\text { ventilation, household } \\
\text { appliances and lighting. }\end{array}$ & $\begin{array}{l}\text { The annual operating energy is } \\
\text { assumed to remain constant } \\
\text { throughout the entire building life } \\
\text { span; } \\
\text { The effects of climate change and } \\
\text { occupants' behaviors in the future } \\
\text { are not taken into consideration. }\end{array}$ & $\begin{array}{l}\text { The approach to quantifying } \\
\text { the embodied energy is not } \\
\text { specified; } \\
\text { Literature is used for obtaining } \\
\text { primary data on embodied } \\
\text { energy }\end{array}$ & $\begin{array}{l}\text { DesignBuilder software is used } \\
\text { to estimate the operational } \\
\text { energy; } \\
\text { The embodied energy } \\
\text { calculation is carried out } \\
\text { multiplying the unit values by } \\
\text { the area of each building } \\
\text { element and summed. }\end{array}$ & None \\
\hline
\end{tabular}


Table A1. Cont.

\begin{tabular}{|c|c|c|c|c|c|c|c|c|c|}
\hline \multirow{2}{*}{ Authors } & \multirow{2}{*}{ Country } & \multirow{2}{*}{ Size $\left(M^{2}\right)$} & \multicolumn{4}{|c|}{ System Boundary } & \multirow{2}{*}{ LCI } & \multirow{2}{*}{ LCIA } & \multirow[t]{2}{*}{ Interpretation } \\
\hline & & & Stage(s) Excluded & $\begin{array}{l}\text { Life Span } \\
\text { (Yrs) }\end{array}$ & Operational Energy & Assumptions & & & \\
\hline $\begin{array}{l}\text { Stephan and } \\
\text { Stephan [30] }\end{array}$ & Lebanon & 904 & EOL & 50 & $\begin{array}{l}\text { Heating, cooling, } \\
\text { ventilation, lighting, DHW, } \\
\text { cooking and appliances }\end{array}$ & $\begin{array}{l}\text { Australian database of } \\
\text { construction materials is used to } \\
\text { calculate the embodied energy; } \\
\text { The embodied energy of } \\
\text { infrastructures used to deliver } \\
\text { energy to the building and life } \\
\text { cycle transport energy demand of } \\
\text { the building's occupants are } \\
\text { considered. }\end{array}$ & $\begin{array}{l}\text { Input-output-based hybrid } \\
\text { approach is used; } \\
\text { Hybrid database of } \\
\text { construction materials } \\
\text { developed by [63]; } \\
\text { Process specific data are } \\
\text { obtained from manufacturers. }\end{array}$ & $\begin{array}{l}\text { DEROB-LTH software is used } \\
\text { to calculate the heating and } \\
\text { cooling loads; } \\
\text { Equation is applied to calculate } \\
\text { operational energy of DHW, } \\
\text { ventilation, cooking, } \\
\text { appliances and lighting; } \\
\text { The embodied energy is } \\
\text { calculated by multiplying the } \\
\text { quantity of materials by their } \\
\text { relevant embodied energy } \\
\text { coefficient. }\end{array}$ & UA, DL \\
\hline $\begin{array}{l}\text { Atmaca and } \\
\text { Atmaca [43] }\end{array}$ & Turkey & $\begin{array}{l}\text { Urban area } \\
(6760) \text { and } \\
\text { rural area } \\
(1320)\end{array}$ & None & 50 & $\begin{array}{l}\text { Heating, cooling, DHW, } \\
\text { lighting, appliances, } \\
\text { cooking }\end{array}$ & $\begin{array}{l}\text { The standard construction } \\
\text { methods and materials are } \\
\text { assumed to remain the same } \\
\text { during the entire building life span; } \\
\text { The structural elements of the } \\
\text { building are assumed to have the } \\
\text { same service life as the house; } \\
\text { All the manufacturing processes } \\
\text { are assumed to be undertaken in } \\
\text { one place; } \\
\text { Only one type of fuel is assumed } \\
\text { to be used for transporting the } \\
\text { wastages. }\end{array}$ & $\begin{array}{l}\text { Process-based approach is } \\
\text { used; } \\
\text { Literature and Inventory of } \\
\text { Carbon and Energy (ICE) } \\
\text { Version } 2.0 \text { are used to obtain } \\
\text { embodied energy of building } \\
\text { materials. }\end{array}$ & $\begin{array}{l}\text { The actual energy consumption } \\
\text { records obtained from utility } \\
\text { bills and questionnaires are } \\
\text { used for estimation of building } \\
\text { operational energy; } \\
\text { The embodied energy } \\
\text { calculation is carried out } \\
\text { multiplying the unit values by } \\
\text { the area of each building } \\
\text { element and summed. }\end{array}$ & DL \\
\hline Rossi et al. [44] & $\begin{array}{l}\text { Belgium, } \\
\text { Portugal and } \\
\text { Sweden }\end{array}$ & 192 & EOL & 50 & $\begin{array}{l}\text { Heating, cooling, DHW, } \\
\text { ventilation, lighting, } \\
\text { building automation and } \\
\text { control }\end{array}$ & $\begin{array}{l}\text { The on-site processes e.g., the } \\
\text { finishing of steel structures } \\
\text { (cutting, shot blasting, welding) } \\
\text { are excluded; } \\
\text { The embodied energy associated } \\
\text { with replacement, refurbishment } \\
\text { and repair of materials and } \\
\text { products are assumed 5\% every } 10 \\
\text { years. } \\
\end{array}$ & $\begin{array}{l}\text { Process-based approach is } \\
\text { used; } \\
\text { BEES, CRTI, ICE and databases } \\
\text { are used to obtain embodied } \\
\text { energy of building materials }\end{array}$ & $\begin{array}{l}\text { LCA analysis has been done } \\
\text { using Equer software, linked to } \\
\text { two other software namely } \\
\text { Pleiades + Comfie }\end{array}$ & SA, DL \\
\hline Stephan et al. [6] & Belgium & 297 & EOL & 100 & $\begin{array}{l}\text { Heating, ventilation, DHW, } \\
\text { lighting, cooking and } \\
\text { appliances }\end{array}$ & $\begin{array}{l}\text { Australian input-output-based } \\
\text { hybrid embodied energy } \\
\text { intensities are used for this case } \\
\text { study that is located in Belgium; } \\
\text { The life cycle transport energy } \\
\text { demands of the building's } \\
\text { occupants are considered; } \\
\text { The recurrent embodied energy of } \\
\text { nearby infrastructures (e.g., roads, } \\
\text { power lines, water and gas } \\
\text { distribution systems and sewage) } \\
\text { is considered. }\end{array}$ & $\begin{array}{l}\text { Input-output-based hybrid } \\
\text { approach is used; } \\
\text { Input-output data is taken } \\
\text { from the Australian National } \\
\text { Accounts; } \\
\text { A database containing } \\
\text { embodied energy coefficients } \\
\text { for materials in Australia } \\
\text { developed by [63] is used. }\end{array}$ & $\begin{array}{l}\text { The LCA analysis is performed } \\
\text { using equations }\end{array}$ & UA \\
\hline
\end{tabular}


Table A1. Cont.

\begin{tabular}{|c|c|c|c|c|c|c|c|c|c|}
\hline \multirow{2}{*}{ Authors } & \multirow{2}{*}{ Country } & \multirow{2}{*}{ Size $\left(M^{2}\right)$} & \multicolumn{4}{|c|}{ System Boundary } & \multirow{2}{*}{ LCI } & \multirow{2}{*}{ LCIA } & \multirow{2}{*}{ Interpretation } \\
\hline & & & Stage(s) Excluded & Life Span (Yrs) & Operational Energy & Assumptions & & & \\
\hline Cellura et al. [45] & Italy & 481.76 & None & 70 & $\begin{array}{l}\text { Heating and cooling, } \\
\text { ventilation, lighting and } \\
\text { plug loads }\end{array}$ & Not discussed. & $\begin{array}{l}\text { Process-based approach is } \\
\text { used; } \\
\text { Literature and SimaPro } \\
\text { database are us; } \\
\text { Data acquired from the local } \\
\text { manufacturer of building } \\
\text { materials. }\end{array}$ & $\begin{array}{l}\text { The annual electricity } \\
\text { requirement of the building is } \\
\text { monitored, and then } \\
\text { normalized for estimating the } \\
\text { building's operational energy; } \\
\text { SimaPro is used to perform the } \\
\text { LCA analysis. }\end{array}$ & None \\
\hline Stephan et al. [5] & $\begin{array}{l}\text { Belgium and } \\
\text { Australia }\end{array}$ & 297 and 330 & EOL & 50 & $\begin{array}{l}\text { Heating, cooling, } \\
\text { ventilation, lighting, DHW, } \\
\text { cooking and appliances }\end{array}$ & $\begin{array}{l}\text { The embodied energy of nearby } \\
\text { infrastructures (e.g., roads, power } \\
\text { lines, water and gas distribution, } \\
\text { and sewage) used to deliver } \\
\text { energy to the building and life } \\
\text { cycle transport energy demand of } \\
\text { the building's occupants are } \\
\text { considered. }\end{array}$ & $\begin{array}{l}\text { Input-output-based hybrid } \\
\text { approach is used; } \\
\text { Input-output data is taken } \\
\text { from the Australian National } \\
\text { Accounts; } \\
\text { A database containing } \\
\text { embodied energy coefficients } \\
\text { for materials in Australia } \\
\text { developed by [63] is used. }\end{array}$ & $\begin{array}{l}\text { Static equations are used to } \\
\text { calculate the operational } \\
\text { energy; } \\
\text { The initial embodied energy is } \\
\text { calculated multiplying the } \\
\text { relevant coefficients by the } \\
\text { final quantities of the } \\
\text { respective materials, and } \\
\text { summed; } \\
\text { The recurrent embodied } \\
\text { energy is calculated via } \\
\text { summing the embodied energy } \\
\text { of replaced materials across the } \\
\text { building's life span. }\end{array}$ & UA \\
\hline Crawford [36] & Australia & 291.3 & None & 50 & $\begin{array}{l}\text { Heating, cooling, } \\
\text { ventilation, lighting, DHW, } \\
\text { cooking and appliances }\end{array}$ & $\begin{array}{l}\text { To account for the contribution of } \\
\text { EOL stage, } 1 \% \text { of the total life cycle } \\
\text { energy demand is summed to the } \\
\text { final achieved figure. }\end{array}$ & $\begin{array}{l}\text { Input-output-based hybrid } \\
\text { approach is used; } \\
\text { Input-output data is taken } \\
\text { from the Australian National } \\
\text { Accounts; Australian process } \\
\text { data obtained from the } \\
\text { SimaPro Australian database. }\end{array}$ & $\begin{array}{l}\text { The energy bills is used to } \\
\text { determine the operational } \\
\text { energy of the house; } \\
\text { The embodied energy is } \\
\text { calculated via multiplying the } \\
\text { quantities of the materials by } \\
\text { their respective energy } \\
\text { coefficients, and summed. }\end{array}$ & DL \\
\hline $\begin{array}{l}\text { Pinky Devi and } \\
\text { Palaniappan [31] }\end{array}$ & India & 32.5 & $\begin{array}{l}\text { Maintenance, repair, } \\
\text { and EOL }\end{array}$ & 50 & $\begin{array}{l}\text { Lighting, ventilation, } \\
\text { appliances and equipment }\end{array}$ & $\begin{array}{l}\text { Assumptions are made where } \\
\text { technical details of building } \\
\text { envelope were unavailable. }\end{array}$ & $\begin{array}{l}\text { Process-based approach is } \\
\text { used; } \\
\text { The relative embodied energy } \\
\text { coefficients are taken from } \\
\text { literature and ICE database. }\end{array}$ & $\begin{array}{l}\text { Data related to the operational } \\
\text { energy are collected from } \\
\text { national statistics; } \\
\text { The embodied energy is } \\
\text { calculated via multiplying the } \\
\text { quantities of the materials by } \\
\text { their respective energy } \\
\text { coefficients, and summed. }\end{array}$ & $\mathrm{SA}, \mathrm{DL}$ \\
\hline $\begin{array}{l}\text { Paulsen and } \\
\text { Sposto [46] }\end{array}$ & Brazil & 48 & Transport & 50 & $\begin{array}{l}\text { Appliances and equipment } \\
\text { and cooking }\end{array}$ & $\begin{array}{l}\text { No analysis of thermal } \\
\text { performance (heating and cooling } \\
\text { for operational energy) has been } \\
\text { performed. }\end{array}$ & $\begin{array}{l}\text { The approach to quantifying } \\
\text { the embodied energy is not } \\
\text { specified; } \\
\text { Data related to the operational } \\
\text { energy are collected from } \\
\text { national statistics; National } \\
\text { Brazilian process data are used } \\
\text { for seven groups of material. } \\
\text { Data from Portugal are also } \\
\text { used for three material groups; } \\
\text { Literature is also used to } \\
\text { extract relative embodied } \\
\text { energy coefficients. }\end{array}$ & $\begin{array}{l}\text { Static equations are used to } \\
\text { calculate the operational } \\
\text { energy; } \\
\text { The embodied energy is } \\
\text { calculated via multiplying the } \\
\text { quantities of the materials by } \\
\text { their respective energy } \\
\text { coefficients, and summed. }\end{array}$ & None \\
\hline
\end{tabular}


Table A1. Cont.

\begin{tabular}{|c|c|c|c|c|c|c|c|c|c|}
\hline \multirow{2}{*}{ Authors } & \multirow[t]{2}{*}{ Country } & \multirow{2}{*}{$\operatorname{Size}\left(M^{2}\right)$} & \multicolumn{4}{|c|}{ System Boundary } & \multirow{2}{*}{ LCI } & \multirow{2}{*}{ LCIA } & \multirow[t]{2}{*}{ Interpretation } \\
\hline & & & Stage(s) Excluded & Life Span (Yrs) & Operational Energy & Assumptions & & & \\
\hline $\begin{array}{c}\text { Devi and } \\
\text { Palaniappan [37] }\end{array}$ & India & 10,800 & $\begin{array}{l}\text { Maintenance, repair, } \\
\text { and renovation }\end{array}$ & 50 & $\begin{array}{l}\text { Lighting, ventilation, and } \\
\text { partial or no } \\
\text { air-conditioning }\end{array}$ & $\begin{array}{l}\text { The building operational energy is } \\
\text { assumed to be same during the } \\
\text { entire building life span; } \\
\text { The embodied energy associated } \\
\text { with EOL is assumed } 3 \% \text { of the } \\
\text { total building life cycle energy } \\
\text { demand. }\end{array}$ & $\begin{array}{l}\text { Process-based approach is } \\
\text { used; } \\
\text { The buildings' energy } \\
\text { consumptions are monitored } \\
\text { for } 21 \text { months and used for } \\
\text { estimating the operational } \\
\text { energy; } \\
\text { The relative embodied energy } \\
\text { coefficients are taken from } \\
\text { literature and ICE. }\end{array}$ & $\begin{array}{l}\text { Data taken from survey, } \\
\text { normalized and used for } \\
\text { calculation of building } \\
\text { operational energy use; } \\
\text { The embodied energy is } \\
\text { calculated via multiplying the } \\
\text { quantities of the materials by } \\
\text { their respective energy } \\
\text { coefficients, and summed. }\end{array}$ & SA \\
\hline Bastos et al. [33] & Portugal & $\begin{array}{l}\text { Type } 2 \text { (367), } \\
\text { Type } 3(472) \\
\text { and type } 8 \\
(1041)\end{array}$ & EOL & 75 & $\begin{array}{l}\text { Heating, cooling, } \\
\text { ventilation, lighting, DHW, } \\
\text { cooking and appliances }\end{array}$ & $\begin{array}{l}\text { The energy consumption is } \\
\text { assumed the same during the } \\
\text { entire building's life span. }\end{array}$ & $\begin{array}{l}\text { Process-based approach is } \\
\text { used; } \\
\text { The Lisbon Energy Matrix data } \\
\text { are used for estimating the } \\
\text { operational energy; } \\
\text { ICE is used for embodied } \\
\text { energy calculation. }\end{array}$ & $\begin{array}{l}\text { The Lisbon Energy Matrix data } \\
\text { are used to calculate the total } \\
\text { energy use per year based on } \\
\text { the ratio between residential } \\
\text { electricity use and natural gas } \\
\text { or LPG; } \\
\text { The embodied energy is } \\
\text { calculated via multiplying the } \\
\text { quantities of the materials by } \\
\text { their respective embodied } \\
\text { energy coefficients, and } \\
\text { summed. }\end{array}$ & DL \\
\hline Ramesh et al. [29] & India & $\begin{array}{c}\text { CS1 (104), CS2 } \\
\text { (185), CS3 (62), } \\
\text { CS4 (183), CS5 } \\
\text { (135), } \\
\text { CS6(175), } \\
\text { CS7(1280), } \\
\text { CS8 (1286), } \\
\text { CS9(450), } \\
\text { CS10(235) }\end{array}$ & $\begin{array}{c}\text { Construction and } \\
\text { EOL }\end{array}$ & 75 & $\begin{array}{l}\text { Heating, cooling, } \\
\text { ventilation, lighting, DHW, } \\
\text { cooking and appliances }\end{array}$ & $\begin{array}{l}\text { The annual operating energy is } \\
\text { assumed to be constant throughout } \\
\text { the entire building life span; } \\
\text { The effects of climate change and } \\
\text { occupants' behaviors in the future } \\
\text { are not taken into consideration. }\end{array}$ & $\begin{array}{l}\text { The approach to quantifying } \\
\text { the embodied energy is not } \\
\text { specified; } \\
\text { The relative embodied energy } \\
\text { coefficients are taken from } \\
\text { literature. }\end{array}$ & $\begin{array}{l}\text { The building operational } \\
\text { energy is estimated using } \\
\text { DesignBuilder software; } \\
\text { The embodied energy is } \\
\text { calculated via multiplying the } \\
\text { quantities of the materials by } \\
\text { theit respective embodied } \\
\text { energy coefficients, and } \\
\text { summed. }\end{array}$ & None \\
\hline Zhan et al. [47] & China & 4235.21 & None & 70 & $\begin{array}{l}\text { Heating, ventilation, air } \\
\text { conditioning, lighting, } \\
\text { appliances and equipment }\end{array}$ & $\begin{array}{l}\text { The operational energy usage } \\
\text { associated with household } \\
\text { appliances is excluded; } \\
\text { Recycling is considered at EOL } \\
\text { stage. }\end{array}$ & $\begin{array}{l}\text { Input-output-based hybrid } \\
\text { approach is used; } \\
\text { National data sources are used } \\
\text { for estimation of embodied } \\
\text { energy such as Guangzhou IO } \\
\text { table, Guangzhou Statistical } \\
\text { Yearbook of 2013, China } \\
\text { Construction Statistical } \\
\text { Yearbook of 2013, and China } \\
\text { Electric Power Yearbook of } \\
\text { 2013. }\end{array}$ & $\begin{array}{l}\text { Static equations are used to } \\
\text { estimate the operational } \\
\text { energy consumption; } \\
\text { Embodied energy is calculated } \\
\text { using hybrid LCA }\end{array}$ & None \\
\hline
\end{tabular}


Table A1. Cont.

\begin{tabular}{|c|c|c|c|c|c|c|c|c|c|}
\hline \multirow{2}{*}{ Authors } & \multirow[t]{2}{*}{ Country } & \multirow{2}{*}{ Size $\left(M^{2}\right)$} & \multicolumn{4}{|c|}{ System Boundary } & \multirow{2}{*}{ LCI } & \multirow{2}{*}{ LCIA } & \multirow{2}{*}{ Interpretation } \\
\hline & & & Stage(s) Excluded & Life Span (Yrs) & Operational Energy & Assumptions & & & \\
\hline $\begin{array}{l}\text { Iyer- Raniga and } \\
\text { Wong [48] }\end{array}$ & Australia & $\underset{a}{\text { Not specified }}$ & None & 100 & Heating and cooling & $\begin{array}{l}\text { All of the materials are assumed to } \\
\text { be landfilled at the EOL stage; } \\
\text { The technology utilized for } \\
\text { material and productions are } \\
\text { assumed to remain unchanged; } \\
\text { due to the lack of available data } \\
\text { regarding to the replacement } \\
\text { lifetimes, the relevant data in US is } \\
\text { used; the resource mix supplying } \\
\text { electricity to the buildings is } \\
\text { assumed static; the occupancy } \\
\text { pattern of buildings is assumed } \\
\text { static. }\end{array}$ & $\begin{array}{l}\text { Process-based approach is } \\
\text { used; } \\
\text { The electricity and water bills } \\
\text { are collected and compared } \\
\text { against the achieved simulated } \\
\text { results for the purpose of } \\
\text { validation; } \\
\text { SimaPro and Australian Unit } \\
\text { Process LCI databases are used } \\
\text { for estimation of buildings' } \\
\text { embodied energy. }\end{array}$ & $\begin{array}{l}\text { The buildings operational } \\
\text { energies are estimated using } \\
\text { AccuRate software; } \\
\text { Embodied energy is calculated } \\
\text { using hybrid LCA }\end{array}$ & SA, DL \\
\hline Dodoo et al. [39] & Sweden & $\begin{array}{l}\text { CLT (928), BC } \\
\text { (928) and MS } \\
\text { (935) }\end{array}$ & $\begin{array}{l}\text { Replacement and } \\
\text { maintenance }\end{array}$ & 50 & $\begin{array}{l}\text { Heating, ventilation, tap } \\
\text { water heating and } \\
\text { appliances and facility } \\
\text { management }\end{array}$ & $\begin{array}{l}\text { The contribution of construction } \\
\text { phase to the total building life } \\
\text { cycle energy is assumed to be } 4 \% \\
\text { of the material production primary } \\
\text { energy; } \\
\text { It is assumed that demolition } \\
\text { energy would not exceed } 10 \\
\mathrm{kWh} / \mathrm{m}^{2} \text { [usable area]. In addition, } \\
90 \% \text { of the demolished concrete, } \\
\text { steel and wood materials are } \\
\text { assumed to be recovered or } \\
\text { recycled during EOL stage. }\end{array}$ & $\begin{array}{l}\text { Process-based approach is } \\
\text { used; } \\
\text { Literature, Ecoinvent v.2.2 } \\
\text { database and SP Technical } \\
\text { Research Institute of Sweden } \\
\text { are used to obtain required } \\
\text { data on embodied energy. }\end{array}$ & $\begin{array}{l}\text { VIP-Energy simulation } \\
\text { software is used to estimate the } \\
\text { final operational energy of the } \\
\text { building; then, the achieved } \\
\text { results are converted to } \\
\text { primary energy using ENSYST } \\
\text { software; } \\
\text { The embodied energy is } \\
\text { calculated via multiplying the } \\
\text { quantities of the materials by } \\
\text { their respective energy } \\
\text { coefficients, and summed. }\end{array}$ & SA \\
\hline Tettey et al. [40] & Sweden & 1686 & $\begin{array}{l}\text { Replacement and } \\
\text { maintenance }\end{array}$ & 80 & $\begin{array}{l}\text { Heating, tap water heating } \\
\text { and electricity for } \\
\text { ventilation }\end{array}$ & $\begin{array}{l}\text { Electricity usages for household } \\
\text { appliances and lighting are } \\
\text { excluded for estimating the } \\
\text { building operational energy; } \\
80 \text { and } 160 \mathrm{kWh} / \mathrm{m}^{2} \text { are assumed } \\
\text { for the on-site energy consumption } \\
\text { of wood and concrete building } \\
\text { systems respectively; } \\
\text { The primary energy use for } \\
\text { demolition of wood and concrete } \\
\text { are assumed to be } 10 \text { and } 20 \\
\mathrm{kWh} / \mathrm{m}^{2} \text { respectively. }\end{array}$ & $\begin{array}{l}\text { Process-based approach is } \\
\text { used; } \\
\text { The relative embodied energy } \\
\text { coefficients are obtained from } \\
\text { literature. }\end{array}$ & $\begin{array}{l}\text { VIP-Energy simulation } \\
\text { software is used to estimate the } \\
\text { final operational energy of the } \\
\text { building; then, the achieved } \\
\text { results are converted to } \\
\text { primary energy using ENSYST } \\
\text { software; } \\
\text { The embodied energy is } \\
\text { calculated via multiplying the } \\
\text { quantities of the materials by } \\
\text { their respective energy } \\
\text { coefficients, and summed. }\end{array}$ & UA \\
\hline Mehta et al. [35] & India & 2588.40 & $\begin{array}{l}\text { On-site construction, } \\
\text { replacement and } \\
\text { maintenance, and } \\
\text { EOL }\end{array}$ & 50 & $\begin{array}{l}\text { Heating, cooling, } \\
\text { ventilation, lighting, DHW, } \\
\text { cooking and appliances }\end{array}$ & $\begin{array}{l}\text { Energy bills of another building } \\
\text { with similar specifications are } \\
\text { used, namely type of the home, } \\
\text { usable floor area per home and the } \\
\text { number of rooms. }\end{array}$ & $\begin{array}{l}\text { Process-based approach is } \\
\text { used; } \\
\text { Operational energy is } \\
\text { calculated using energy bills; } \\
\text { ICE is used to calculate } \\
\text { embodied energy. }\end{array}$ & $\begin{array}{l}\text { Operational energy is } \\
\text { calculated using energy bills; } \\
\text { The embodied energy is } \\
\text { calculated via multiplying the } \\
\text { quantities of the materials by } \\
\text { their respective energy } \\
\text { coefficients, and summed. }\end{array}$ & SA \\
\hline
\end{tabular}


Table A1. Cont.

\begin{tabular}{|c|c|c|c|c|c|c|c|c|c|}
\hline \multirow{2}{*}{ Authors } & \multirow{2}{*}{ Country } & \multirow{2}{*}{ Size $\left(\mathbf{M}^{2}\right)$} & \multicolumn{4}{|c|}{ System Boundary } & \multirow{2}{*}{ LCI } & \multirow{2}{*}{ LCIA } & \multirow{2}{*}{ Interpretation } \\
\hline & & & Stage(s) Excluded & Life Span (Yrs) & Operational Energy & Assumptions & & & \\
\hline Zhu et al. [41] & China & $\begin{array}{l}6890 \text { and } \\
216,200\end{array}$ & $\begin{array}{l}\text { EOL, Replacement } \\
\text { and maintenance }\end{array}$ & 50 & $\begin{array}{l}\text { Heating and cooling, } \\
\text { lighting and appliances }\end{array}$ & $\begin{array}{l}\text { The effects of on-site construction } \\
\text { management skill is ignored. }\end{array}$ & $\begin{array}{l}\text { Input-output-based hybrid } \\
\text { approach is used; } \\
\text { The input-output table } \\
\text { developed by Chinese National } \\
\text { Bureau of Statistics is used; } \\
\text { The process-based energy } \\
\text { intensity data are acquired } \\
\text { from the China Building } \\
\text { Material Academy and the } \\
\text { Chinese Life Cycle Database } \\
\text { developed by Sichuan } \\
\text { University. }\end{array}$ & $\begin{array}{l}\text { DesignBuilder software is used } \\
\text { to estimate the building's } \\
\text { operational energy; } \\
\text { The embodied energy is } \\
\text { calculated via multiplying the } \\
\text { quantities of the materials by } \\
\text { their respective energy } \\
\text { coefficients, and summed. }\end{array}$ & None \\
\hline Bastos et al. [32] & Portugal & $\begin{array}{l}\text { CA (102) and } \\
\text { SH (104) }\end{array}$ & EOL & 50 & $\begin{array}{l}\text { Heating, cooling, } \\
\text { ventilation, lighting, DHW, } \\
\text { cooking and appliances }\end{array}$ & $\begin{array}{l}\text { This study accounts for user } \\
\text { transportation. }\end{array}$ & $\begin{array}{l}\text { Process-based approach is } \\
\text { used; The Ecoinvent database } \\
\text { is used for quantification of the } \\
\text { building's embodied energy. }\end{array}$ & $\begin{array}{l}\text { The ratio between residential } \\
\text { electricity use and natural gas } \\
\text { or LPG from the Lisbon Energy } \\
\text { Matrix is used to calculate the } \\
\text { total operational energy use } \\
\text { per year. }\end{array}$ & SA \\
\hline Goggins et al. [49] & Ireland & 106 & $\begin{array}{l}\text { Replacement and } \\
\text { maintenance }\end{array}$ & 60 & $\begin{array}{l}\text { Lighting, ventilation, and } \\
\text { DHW }\end{array}$ & $\begin{array}{l}90 \% \text { of the building materials are } \\
\text { assumed to be recycled at the EOL } \\
\text { of building and used for secondary } \\
\text { purposes; } \\
\text { No change in fuel mix would } \\
\text { occur over building life span. }\end{array}$ & $\begin{array}{l}\text { Process-based approach is } \\
\text { used; } \\
\text { ICE is used to calculate } \\
\text { embodied energy. }\end{array}$ & $\begin{array}{l}\text { DEAP software is used to } \\
\text { estimate the operational } \\
\text { energy; } \\
\text { The embodied energy is } \\
\text { calculated via multiplying the } \\
\text { quantities of the materials by } \\
\text { their respective energy } \\
\text { coefficients, and summed. }\end{array}$ & None \\
\hline $\begin{array}{l}\text { Kristjansdottir et } \\
\text { al. [50] }\end{array}$ & Norway & 120 & $\begin{array}{l}\text { Construction and } \\
\text { EOL }\end{array}$ & 60 & $\begin{array}{l}\text { Lighting, heating, } \\
\text { appliances, ventilation, } \\
\text { DHW. }\end{array}$ & $\begin{array}{l}\text { Replacement of PV panels are } \\
\text { assumed to have } 50 \% \text { of the initial } \\
\text { embodied energy load. }\end{array}$ & $\begin{array}{l}\text { Process-based approach is } \\
\text { used; } \\
\text { Ecoinvent v3.2 database is used } \\
\text { to calculate embodied energy. }\end{array}$ & $\begin{array}{l}\text { IDA-ICE software is used to } \\
\text { calculate the operating energy; } \\
\text { Brightway2 is used to perform } \\
\text { impact assessment. }\end{array}$ & $\mathrm{DL}, \mathrm{SA}$ \\
\hline $\begin{array}{l}\text { Mistretta et al. } \\
{[51]}\end{array}$ & Italy & 481.76 & None & 70 & $\begin{array}{l}\text { Heating and cooling, } \\
\text { ventilation, DHW, lighting, } \\
\text { and appliances. }\end{array}$ & Not discussed. & $\begin{array}{l}\text { Process-based approach is } \\
\text { used; } \\
\text { Process data are obtained from } \\
\text { local manufacturers; } \\
\text { Ecoinvent database is used to } \\
\text { retrieve data about recycling of } \\
\text { aluminum, steel, glass, and } \\
\text { copper. }\end{array}$ & $\begin{array}{l}\text { TRNSYS software is used to } \\
\text { estimate operating energy in } \\
\text { the refurbished building. } \\
\text { For the baseline building, } \\
\text { energy use is monitored; } \\
\text { SimpaPro is used to assess the } \\
\text { environmental impacts. }\end{array}$ & None \\
\hline
\end{tabular}

Abbreviations: LCI: Life cycle inventory; LCIA: Life cycle impact assessment; Interpretation stage: Sensitivity Analysis (SA); Uncertainty Analysis (UA); Discussion of Limitations (DL); Case study (CS). Note: (a) the sizes of buildings are not specified, and results are reported in $\mathrm{MJ} / \mathrm{m}^{2}$. 


\section{Appendix B}

Table A2. Normalized operational energy and embodied energy of analyzed studies.

\begin{tabular}{|c|c|c|c|c|}
\hline Authors & Building Character & Case Study ID & Embodied Energy $\left(\mathrm{kWh} / \mathrm{m}^{2}\right.$.year) & Operational Energy $\left(\mathrm{kWh} / \mathrm{m}^{2}\right.$.year) \\
\hline \multirow{3}{*}{ Aye et al. [27] } & Steel structure & CS1 & Steel (80) & Steel (119.88) \\
\hline & Concrete structure & CS2 & Concrete (53.55) & Concrete (112.54) \\
\hline & Timber structure & CS3 & Timber (58.29) & Timber (117.57) \\
\hline Gustavsson et al. [38] & Wood-framed apartment & CS4 & Assumed 50 years of life span (-15.38) & Assumed 50 years of life span (176.86) \\
\hline \multirow{6}{*}{ Dodoo and Gustavsson [42] } & Conventional building with EH system & CS5 & Conventional building with EH $(-1.56)$ & Conventional building with EH (278.64) \\
\hline & Conventional building with HPH system & CS6 & Conventional building with HPH (-1.56) & Conventional building with HPH (201.7) \\
\hline & Conventional building with DH system & CS7 & Conventional building with DH $(-1.56)$ & Conventional building with DH (187.26) \\
\hline & Passive building with EH system & CS8 & Passive building with EH(-1.66) & Passive building with EH(250.8) \\
\hline & Passive building with HPH system & CS9 & Passive building with HPH (-1.66) & Passive building with HPH (192.12) \\
\hline & Passive building with DH system & CS10 & Passive building with $\mathrm{DH}(-1.66)$ & Passive building with DH(181.08) \\
\hline \multirow{4}{*}{ Ramesh et al. [28] } & Building with fired clay exterior walls & CS11 & Building with fired clay exterior walls (29) & Building with fired clay exterior walls (174) \\
\hline & Building with hollow concrete exterior walls & CS12 & Building with hollow concrete exterior walls (27) & $\begin{array}{l}\text { Building with hollow concrete exterior walls } \\
\text { (172) }\end{array}$ \\
\hline & $\begin{array}{l}\text { Building with soil cement exterior walls } \\
\text { Building with fly ash exterior walls }\end{array}$ & $\begin{array}{l}\text { CS13 } \\
\text { CS14 }\end{array}$ & $\begin{array}{l}\text { Building with soil cement exterior walls (27) } \\
\text { Building with fly ash exterior walls (28) }\end{array}$ & $\begin{array}{l}\text { Building with soil cement exterior walls (171) } \\
\text { Building with fly ash exterior walls (169) }\end{array}$ \\
\hline & Building with aerated concrete exterior walls & CS15 & Building with aerated concrete exterior walls (27) & $\begin{array}{c}\text { Building with aerated concrete exterior walls } \\
\text { (167) }\end{array}$ \\
\hline Stephan and Stephan [30] & Apartment buildings & CS16 & 150 & 266.66 \\
\hline \multirow{2}{*}{ Atmaca and Atmaca [43] } & Building located in urban area & CS17 & Urban area (43.33) & Urban area (167.22) \\
\hline & Building located in urban rural & CS18 & Rural area (26.11) & Rural area (135.55) \\
\hline \multirow{3}{*}{ Rossi et al. [44] } & Residential building located in Belgium & CS19 & Belgium (24.39) & Belgium (274.41) \\
\hline & Residential building located in Portugal & CS20 & Portugal (24.39) & Portugal (174.72) \\
\hline & Residential building located in Sweden & CS21 & Sweden (26.18) & Sweden (327.79) \\
\hline Stephan et al. [6] & Passive house & CS22 & 131 & 39.5 \\
\hline Cellura et al. [45] & Net zero energy building & CS23 & 137.82 & 48.42 \\
\hline \multirow{2}{*}{ Stephan et al. [5] } & Passive house - Brussels, Belgium & CS24 & Belgium (143.48) & Belgium (99.41) \\
\hline & $\begin{array}{l}\text { 7-Star building (highenergy efficiency } \\
\text { standards) - Melbourne, Australia }\end{array}$ & $\mathrm{CS} 25$ & Australia (130) & Australia (160.62) \\
\hline Crawford [36] & Insulated timber-framed brick veneer walls & CS26 & 120.88 & 81.66 \\
\hline $\begin{array}{l}\text { Pinky Devi and Palaniappan } \\
{[31]}\end{array}$ & Low-cost house & CS27 & 37.25 & 92.65 \\
\hline Paulsen and Sposto [46] & Low-cost house & CS28 & 43.97 & 97.57 \\
\hline Devi and Palaniappan [37] & Multi-story residential building apartment & CS29 & 72.77 & 116.66 \\
\hline
\end{tabular}


Table A2. Cont.

\begin{tabular}{|c|c|c|c|c|}
\hline Authors & Building Character & Case Study ID & Embodied Energy $\left(\mathrm{kWh} / \mathrm{m}^{2}\right.$. year) & Operational Energy $\left(\mathrm{kWh} / \mathrm{m}^{2}\right.$.year) \\
\hline \multirow{3}{*}{ Bastos et al. [33] } & $\begin{array}{c}\text { Conventional residential buildings with the } \\
\text { area of } 367 \mathrm{~m}^{2}\end{array}$ & CS30 & Type 2 (15.47) & Type $2(74.64)$ a \\
\hline & $\begin{array}{l}\text { Conventional residential buildings with the } \\
\text { area of } 472 \mathrm{~m}^{2}\end{array}$ & CS31 & Type 3 (15.11) & Type $3(59.33)$ a \\
\hline & $\begin{array}{l}\text { Conventional residential buildings with the } \\
\text { area of } 1041 \mathrm{~m}^{2}\end{array}$ & CS32 & Type 8 (13.87) & Type 8 (37.77) a \\
\hline \multirow{20}{*}{ Ramesh et al. [29] } & Conventional building located in Keerthi & CS 33 & CS1-Conventional system (28.12) & CS1-Conventional system (348) \\
\hline & Conventional building located in Eashwer & CS 34 & CS2-Conventional system (21.17) & CS2-Conventional system (271) \\
\hline & Conventional building located in Adil & CS 35 & CS3-Conventional system (27.4) & CS3-Conventional system (303) \\
\hline & Conventional building located in Anand & CS 36 & CS4-Conventional system (21.49) & CS4-Conventional system (264) \\
\hline & Conventional building located in Alwal & CS 37 & CS5-Conventional system (18.56) & CS5-Conventional system (279) \\
\hline & Conventional building located in RG & CS 38 & CS6-Conventional system (22.12) & CS6-Conventional system (296) \\
\hline & Conventional building located in Rock town & CS 39 & CS7-Conventional system (23.27) & CS7-Conventional system (325) \\
\hline & $\begin{array}{l}\text { Conventional building located in Kiran } \\
\text { Arcade }\end{array}$ & CS 40 & CS8-Conventional system (21.8) & CS8-Conventional system (250) \\
\hline & Conventional building located in Mahendra & CS 41 & CS9-Conventional system (24.54) & CS9-Conventional system (309) \\
\hline & Conventional building located in Nirmal & CS 42 & CS10-Conventional system (23.50) & CS10-Conventional system (280) \\
\hline & Insulated building located in Keerthi & CS 43 & CS1-Insulated envelope (30.63) & CS1-Insulated envelope (234) \\
\hline & Conventional building located in Eashwer & CS 44 & CS2-Insulated envelope (22.69) & CS2-Insulated envelope (237) \\
\hline & Insulated building located in Adil & CS 45 & CS3-Insulated envelope (29.45) & CS3-Insulated envelope (245) \\
\hline & Conventional building located in Anand & CS 46 & CS4-Insulated envelope (27.08) & CS4-Insulated envelope (230) \\
\hline & Insulated building located in Alwal & CS 47 & CS5-Insulated envelope (20.87) & CS5-Insulated envelope (219) \\
\hline & Insulated building located in RG & CS 48 & CS6-Insulated envelope (23.90) & CS6-Insulated envelope (261) \\
\hline & Insulated building located in Rock town & CS 49 & CS7-Insulated envelope (24.65) & CS7-Insulated envelope (310) \\
\hline & Insulated building located in Kiran Arcade & CS 50 & CS8-Insulated envelope (22.87) & CS8-Insulated envelope (238) \\
\hline & Insulated building located in Mahendra & CS 51 & CS9-Insulated envelope (27.07) & CS9-Insulated envelope (285) \\
\hline & Insulated building located in Nirmal & CS 52 & CS10-Insulated envelope (25.19) & CS10-Insulated envelope (248) \\
\hline Zhan et al. [47] & $\begin{array}{l}\text { Typical residential building located in urban } \\
\text { area }\end{array}$ & CS 53 & 22.77 & 45.19 \\
\hline \multirow{8}{*}{ Iyer- Raniga and Wong [48] } & Heritage building with brick veneer envelope & CS 54 & CS1 (63.61) & CS1 (45.00) \\
\hline & $\begin{array}{l}\text { Heritage building with weatherboard } \\
\text { envelope }\end{array}$ & CS 55 & CS2 (314.4) & CS2 (193.90) \\
\hline & $\begin{array}{l}\text { Heritage building with weatherboard } \\
\text { envelope }\end{array}$ & CS 56 & CS3 (118.33) & CS3 (170.50) \\
\hline & $\begin{array}{l}\text { Heritage building with weatherboard } \\
\text { envelope }\end{array}$ & CS 57 & CS4 (161.38) & CS4 (116.38) \\
\hline & Heritage building with brick veneer envelope & CS 58 & CS5 (180) & CS5 (108.80) \\
\hline & Heritage building with solid brick & CS 59 & CS6 (134.16) & CS6 (88.00) \\
\hline & Heritage building with solid brick & CS 60 & CS7 (137.22) & CS7 (82.22) \\
\hline & Heritage building with brick veneer envelope & CS 61 & CS8 (143.8) & CS8 (83.88) \\
\hline
\end{tabular}


Table A2. Cont.

\begin{tabular}{|c|c|c|c|c|}
\hline Authors & Building Character & Case Study ID & Embodied Energy $\left(\mathrm{kWh} / \mathrm{m}^{2}\right.$. year) & Operational Energy ( $\mathrm{kWh} / \mathrm{m}^{2}$.year) \\
\hline \multirow{6}{*}{ Dodoo et al. [39] } & $\begin{array}{l}\text { Cross laminated timber structure with heat } \\
\text { pump heated system }\end{array}$ & CS 62 & CLT $(-18.36)$ & CLT with HPH system (187) \\
\hline & $\begin{array}{l}\text { Beam-and-Column system structure with } \\
\text { heat pump heated system }\end{array}$ & CS 63 & BC $(-14.2)$ & BC with HPH (192) \\
\hline & $\begin{array}{l}\text { Modular timber structure with heat pump } \\
\text { heated system }\end{array}$ & CS 64 & MT (-3.5) & MT with HPH (192) \\
\hline & $\begin{array}{l}\text { Cross laminated timber structure with } \\
\text { district heated system }\end{array}$ & CS 65 & CLT $(-18.36)$ & CLT with DH system (176) \\
\hline & $\begin{array}{l}\text { Beam-and-Column system structure with } \\
\text { district heated system }\end{array}$ & CS 66 & $\mathrm{BC}(-14.2)$ & BC with DH (180) \\
\hline & $\begin{array}{c}\text { Modular timber structure with district } \\
\text { heated system }\end{array}$ & CS 67 & MT $(-3.5)$ & MT with DH (180) \\
\hline \multirow{5}{*}{ Tettey et al. [40] } & Standard building with concrete system & CS 68 & Standard building with concrete system (8.775) & Standard building with concrete system (137.47) \\
\hline & $\begin{array}{l}\text { Standard building with cross laminated } \\
\text { timber structure }\end{array}$ & CS 69 & Standard building with CLT $(-20.18)$ & Standard building with CLT (137.47) \\
\hline & $\begin{array}{l}\text { Standard building with modular timber } \\
\text { structure }\end{array}$ & CS 70 & Standard building with MT $(-4.43)$ & Standard building with MT (137.47) \\
\hline & Passive building with concrete system & CS 71 & Passive building with concrete system (9.52) & Passive building with concrete system (71.16) \\
\hline & $\begin{array}{l}\text { Passive building with modular timber } \\
\text { structure }\end{array}$ & CS 72 & Passive building with MT (-4.03) & Passive building with MT (71.16) \\
\hline Mehta et al. [35] & Multi-story residential building & CS 73 & 34.75 & 179.70 \\
\hline \multirow[t]{2}{*}{ Zhu et al. [41] } & $\begin{array}{c}\text { Prefabricated buildings located in Chengdu, } \\
\text { China }\end{array}$ & CS 74 & CS A (33.94) & CS A (86.11) \\
\hline & $\begin{array}{c}\text { Prefabricated buildings located in Shenzhen, } \\
\text { China }\end{array}$ & CS 75 & CS B (28.00) & CS B (113.88) \\
\hline \multirow[t]{2}{*}{ Bastos et al. [32] } & City apartment & CS 76 & CA (15.02) & CA (70.77) \\
\hline & Suburban house & CS 77 & SH (17.75) & SH (75.19) \\
\hline \multirow{6}{*}{ Goggins et al. [49] } & $\begin{array}{c}\text { Baseline building constructed according to } \\
2005 \text { Irish regulations. Airtightness } 9.1 \\
\text { ac/hr@ } 50 \text { Pa. }\end{array}$ & CS 78 & 16.725 & 131.26 \\
\hline & $\begin{array}{l}\text { Building constructed according to } 2008 \text { Irish } \\
\text { regulations. Airtightness } 5.44 \mathrm{ac} / \mathrm{hr} @ 50 \text { Pa. }\end{array}$ & CS 79 & 17.06 & 100.96 \\
\hline & $\begin{array}{l}\text { Building constructed according to } 2011 \text { Irish } \\
\text { regulations. Airtightness 5.44 ac/hr@ } 50 \text { Pa. }\end{array}$ & CS 80 & 20.07 & 85.23 \\
\hline & $\begin{array}{l}\text { Building constructed according to } 2011 \text { Irish } \\
\text { regulations. Airtightness } 0.45 \mathrm{ac} / \mathrm{hr} @ 50 \text { Pa. }\end{array}$ & CS 81 & 18.73 & 83.07 \\
\hline & NZEB Airtightness 5.44 ac/hr@ 50 Pa. & CS 82 & 21.24 & 78.59 \\
\hline & NZEB. Airtightness 0.45 ac/hr@ 50 Pa. & CS 83 & 19.56 & 79.07 \\
\hline Kristjansdottir et al. [50] & NZEB & CS 84 & 80.30 & 55.50 \\
\hline \multirow{2}{*}{ Mistretta et al. [51] } & Baseline building & CS 85 & 137.86 & 12.80 \\
\hline & NZEB (retrofitted) & CS 86 & 49.20 & -90.0 \\
\hline
\end{tabular}

Abbreviations: Cross laminated timber (CLT) system, Beam-and-Column system (BC), Modular timber system (MT); City apartment (CA); Suburban house (SH); Electric heated (EH); Heat pump heated (HPH); District heated (DH); Case study (CS). Notes: (a) this paper reports the operational energy with conversion factor of 2.5; (b) the sizes of buildings are not specified, and results are reported in $\mathrm{MJ} / \mathrm{m}^{2}$. 


\section{References}

1. Nejat, P.; Jomehzadeh, F.; Taheri, M.M.; Gohari, M.; Majid, M.Z.A. A global review of energy consumption, $\mathrm{CO}_{2}$ emissions and policy in the residential sector (with an overview of the top ten $\mathrm{CO}_{2}$ emitting countries). Renew. Sustain. Energy Rev. 2015, 43, 843-862. [CrossRef]

2. Soltani, A.; Mehraein, M.; Sharifi, E. Urban features and energy consumption at local level. JUEE 2012, 6, 43-47. [CrossRef]

3. Omrany, H.; Ghaffarianhoseini, A.; Ghaffarianhoseini, A.; Raahemifar, K.; Tookey, J. Application of passive wall systems for improving the energy efficiency in buildings: A comprehensive review. Renew. Sustain. Energy Rev. 2016, 62, 1252-1269. [CrossRef]

4. Moncaster, A.M.; Rasmussen, F.N.; Malmqvist, T.; Wiberg, A.H.; Birgisdottir, H. Widening understanding of low embodied impact buildings: Results and recommendations from 80 multi-national quantitative and qualitative case studies. J. Clean. Prod. 2019, 235, 378-393. [CrossRef]

5. Stephan, A.; Crawford, R.H.; De Myttenaere, K. Towards a comprehensive life cycle energy analysis framework for residential buildings. Energy Build. 2012, 55, 592-600. [CrossRef]

6. Stephan, A.; Crawford, R.H.; De Myttenaere, K. A comprehensive assessment of the life cycle energy demand of passive houses. Appl. Energy 2013, 112, 23-34. [CrossRef]

7. Crawford, R.H.; Bartak, E.L.; Stephan, A.; Jensen, C.A. Evaluating the life cycle energy benefits of energy efficiency regulations for buildings. Renew. Sustain. Energy Rev. 2016, 63, 435-451. [CrossRef]

8. Malmqvist, T.; Nehasilova, M.; Moncaster, A.; Birgisdottir, H.; Rasmussen, F.N.; Wiberg, A.H.; Potting, J. Design and construction strategies for reducing embodied impacts from buildings-Case study analysis. Energy Build. 2018, 166, 35-47. [CrossRef]

9. Chau, C.K.; Leung, T.M.; Ng, W.Y. A review on life-cycle assessment, life-cycle energy assessment and life-cycle carbon emissions assessment on buildings. Appl. Energy 2015, 143, 395-413. [CrossRef]

10. Dixit, M.K.; Fernández-Solís, J.L.; Lavy, S.; Culp, C.H. Identification of parameters for embodied energy measurement: A literature review. Energy Build. 2010, 42, 1238-1247. [CrossRef]

11. Dixit, M.K. Life cycle embodied energy analysis of residential buildings: A review of literature to investigate embodied energy parameters. Renew. Sustain. Energy Rev. 2017, 79, 390-413. [CrossRef]

12. Dixit, M.K.; Culp, C.H.; Fernández-Solís, J.L. System boundary for embodied energy in buildings: A conceptual model for definition. Renew. Sustain. Energy Rev. 2013, 21, 153-164. [CrossRef]

13. Dixit, M.K.; Fernández-Solís, J.L.; Lavy, S.; Culp, C.H. Need for an embodied energy measurement protocol for buildings: A review paper. Renew. Sustain. Energy Rev. 2012, 16, 3730-3743. [CrossRef]

14. Karimpour, M.; Belusko, M.; Xing, K.; Bruno, F. Minimizing the life-cycle energy of buildings: Review and analysis. Build. Environ. 2014, 73, 106-114. [CrossRef]

15. Cabeza, L.F.; Rincón, L.; Vilariño, V.; Pérez, G.; Castell, A. Life cycle assessment (LCA) and life cycle energy analysis (LCEA) of buildings and the building sector: A review. Renew. Sustain. Energy Rev. 2014, 29, 394-416. [CrossRef]

16. Khasreen, M.; Banfill, P.F.; Menzies, G. Life-cycle assessment and the environmental impact of buildings: A review. Sustainability 2009, 1, 674-701. [CrossRef]

17. Švajlenka, J.; Kozlovská, M. Houses based on wood as an ecological and sustainable housing alternative-case study. Sustainability 2018, 10, 1502. [CrossRef]

18. Švajlenka, J.; Kozlovská, M. Effect of accumulation elements on the energy consumption of wood constructions. Energy Build. 2019, 198, 160-169. [CrossRef]

19. Pryshlakivsky, J.; Searcy, C. Fifteen years of ISO 14040: A review. J. Clean. Prod. 2013, 57, 115-123. [CrossRef]

20. ISO. Environmental Management-Life Cycle Assessment-Requirements and Guidelines; International Organization for Standardization: Geneva, Switzerland, 2006.

21. ISO. Environmental Management: Life Cycle Assessment-Principles and Framework; International Organization for Standardization: Geneva, Switzerland, 2006.

22. Singh, A.; Berghorn, G.; Joshi, S.; Syal, M. Review of life-cycle assessment applications in building construction. J. Build. Eng. 2010, 17, 15-23. [CrossRef]

23. Ramesh, T.; Prakash, R.; Shukla, K.K. Life-cycle energy analysis of buildings: An overview. Energy Build. 2010, 42, 1592-1600. [CrossRef] 
24. Fay, R.; Graham, T.; lyer-Raniga, U. Life-cycle energy analysis of buildings: A case study. Build. Res Inf. 2000, 28, 31-41. [CrossRef]

25. Omrany, H.; Ghaffarianhoseini, A.; Berardi, U.; Ghaffarianhoseini, A.; Li, D.H. Is atrium an ideal form for daylight in buildings? Archit. Sci. Rev. 2019, 1-16. [CrossRef]

26. Ghaffarianhoseini, A.; AlWaer, H.; Omrany, H.; Ghaffarianhoseini, A.; Alalouch, C.; Clements-Croome, D.; Tookey, J. Sick building syndrome: Are we doing enough? Archit. Sci. Rev. 2018, 61, 99-121. [CrossRef]

27. Aye, L.; Ngo, T.; Crawford, R.H.; Gammampila, R.; Mendis, P. Life cycle greenhouse gas emissions and energy analysis of prefabricated reusable building modules. Energy Build. 2012, 47, 159-168. [CrossRef]

28. Ramesh, T.; Prakash, R.; Shukla, K.K. Life cycle energy analysis of a residential building with different envelopes and climates in Indian context. Appl. Energy 2012, 89, 193-202. [CrossRef]

29. Ramesh, T.; Prakash, R.; Shukla, K.K. Life cycle approach in evaluating energy performance of residential buildings in Indian context. Energy Build. 2012, 54, 259-265. [CrossRef]

30. Stephan, A.; Stephan, L. Reducing the total life-cycle energy demand of recent residential buildings in Lebanon. Energy 2014, 74, 618-637. [CrossRef]

31. Pinky Devi, L.; Palaniappan, S. Life cycle energy analysis of a low-cost house in India. Intl. J. Cons. Edu. Res. 2018, 1-20. [CrossRef]

32. Bastos, J.; Batterman, S.A.; Freire, F. Significance of mobility in the life-cycle assessment of buildings. Build. Res. Inf. 2016, 44, 376-393. [CrossRef]

33. Bastos, J.; Batterman, S.A.; Freire, F. Life-cycle energy and greenhouse gas analysis of three building types in a residential area in Lisbon. Energy Build. 2014, 69, 344-353. [CrossRef]

34. Praseeda, K.I.; Reddy, B.V.; Mani, M. Embodied and operational energy of urban residential buildings in India. Energy Build. 2016, 110, 211-219. [CrossRef]

35. Mehta, S.; Chandur, A.; Palaniappan, S. Life Cycle Energy Assessment of a Multi-storey Residential Building. J. Inst. Eng. India Ser. A 2017, 98, 155-162. [CrossRef]

36. Crawford, R.H. Post-occupancy life cycle energy assessment of a residential building in Australia. Archit. Sci. Rev. 2014, 57, 114-124. [CrossRef]

37. Devi, P.; Palaniappan, S. A case study on life cycle energy use of residential building in Southern India. Energy Build. 2014, 80, 247-259. [CrossRef]

38. Gustavsson, L.; Joelsson, A.; Sathre, R. Life cycle primary energy use and carbon emission of an eight-storey wood-framed apartment building. Energy Build. 2010, 42, 230-242. [CrossRef]

39. Dodoo, A.; Gustavsson, L.; Sathre, R. Lifecycle primary energy analysis of low-energy timber building systems for multi-storey residential buildings. Energy Build. 2014, 81, 84-97. [CrossRef]

40. Tettey, U.Y.A.; Dodoo, A.; Gustavsson, L. Effect of different frame materials on the primary energy use of a multi storey residential building in a life cycle perspective. Energy Build. 2019, 185, 259-271. [CrossRef]

41. Zhu, H.; Hong, J.; Shen, G.Q.; Mao, C.; Zhang, H.; Li, Z. The exploration of the life-cycle energy saving potential for using prefabrication in residential buildings in China. Energy Build. 2018, 166, 561-570. [CrossRef]

42. Dodoo, A.; Gustavsson, L. Life cycle primary energy use and carbon footprint of wood-frame conventional and passive houses with biomass-based energy supply. Appl. Energy 2013, 112, 834-842. [CrossRef]

43. Atmaca, A.; Atmaca, N. Life cycle energy (LCEA) and carbon dioxide emissions (LCCO2A) assessment of two residential buildings in Gaziantep, Turkey. Energy Build. 2015, 102, 417-431. [CrossRef]

44. Rossi, B.; Marique, A.F.; Reiter, S. Life-cycle assessment of residential buildings in three different European locations, case study. Build. Environ. 2012, 51, 402-407. [CrossRef]

45. Cellura, M.; Guarino, F.; Longo, S.; Mistretta, M. Energy life-cycle approach in Net zero energy buildings balance: Operation and embodied energy of an Italian case study. Energy Build. 2014, 72, 371-381. [CrossRef]

46. Paulsen, J.S.; Sposto, R.M. A life cycle energy analysis of social housing in Brazil: Case study for the program "MY HOUSE MY LIFE". Energy Build. 2013, 57, 95-102. [CrossRef]

47. Zhan, J.; Liu, W.; Wu, F.; Li, Z.; Wang, C. Life cycle energy consumption and greenhouse gas emissions of urban residential buildings in Guangzhou city. J. Clean. Prod. 2018, 194, 318-326. [CrossRef]

48. Iyer-Raniga, U.; Wong, J.P.C. Evaluation of whole life-cycle assessment for heritage buildings in Australia. Build. Environ. 2012, 47, 138-149. [CrossRef]

49. Goggins, J.; Moran, P.; Armstrong, A.; Hajdukiewicz, M. Lifecycle environmental and economic performance of nearly zero energy buildings (NZEB) in Ireland. Energy Build. 2016, 116, 622-637. [CrossRef] 
50. Kristjansdottir, T.F.; Houlihan-Wiberg, A.; Andresen, I.; Georges, L.; Heeren, N.; Good, C.S.; Brattebø, H. Is a net life cycle balance for energy and materials achievable for a zero emission single-family building in Norway? Energy Build. 2018, 168, 457-469. [CrossRef]

51. Mistretta, M.; Arcoleo, M.; Cellura, M.; Cesarini, D.N.; Guarino, F.; Longo, S. Refurbishment scenario to shift nearly net ZEBs toward net ZEB target: An Italian case study. In Nearly Zero Energy Building Refurbishment; Springer: London, UK, 2013; pp. 233-252. [CrossRef]

52. Gustavsson, L.; Joelsson, A. Life cycle primary energy analysis of residential buildings. Energy Build. 2010, 42, 210-220. [CrossRef]

53. CIRCE. ENSLIC BUILDING-energy Saving through Promotion of Life Cycle Assessment in Buildings, D 4.2. In CIRCE. Pilot Case 3, in ENSLIC-CIRCE-WP4-Pilot Cases-published on Intelligent Energy Europe; Intelligent Energy Europe; European Union: Brussel, Belgium, 2010.

54. Grant, A.; Ries, R. Impact of building service life models on life cycle assessment. Build Res. Inf. 2013, 41, 168-186. [CrossRef]

55. Rauf, A.; Crawford, R.H. Building service life and its effect on the life cycle embodied energy of buildings. Energy 2015, 79, 140-148. [CrossRef]

56. Fufa, S.M.; Wiik, M.R.K.; Schlanbusch, R.D.; Andresen, I. The influence of estimated service life on the embodied emissions of zero emission buildings (ZEBs) when choosing low-carbon building products. In XIV DBMC-14th International Conference on Durability of Building Materials and Components; Rilem publications: Ghent, Belgium, 2017.

57. Crawford, R.H.; Bontinck, P.A.; Stephan, A.; Wiedmann, T.; Yu, M. Hybrid life cycle inventory methods-A review. J. Clean. Prod. 2018, 172, 1273-1288. [CrossRef]

58. Chastas, P.; Theodosiou, T.; Bikas, D. Embodied energy in residential buildings-towards the nearly zero energy building: A literature review. Build. Environ. 2016, 105, 267-282. [CrossRef]

59. Yung, P.; Lam, K.C.; Yu, C. An audit of life cycle energy analyses of buildings. Habitat Int. 2013, 39, 43-54. [CrossRef]

60. Sartori, I.; Hestnes, A.G. Energy use in the life cycle of conventional and low-energy buildings: A review article. Energy Build. 2007, 39, 249-257. [CrossRef]

61. Thibodeau, C.; Bataille, A.; Sié, M. Building rehabilitation life cycle assessment methodology-state of the art. Renew. Sustain. Energy Rev. 2019, 103, 408-422. [CrossRef]

62. Sicignano, E.; Di Ruocco, G.; Melella, R. Mitigation Strategies for Reduction of Embodied Energy and Carbon, in the Construction Systems of Contemporary Quality Architecture. Sustainability 2019, 11, 3806. [CrossRef]

63. Treloar, G.J.; Crawford, R.H. Database of Embodied Energy and Water Values for Materials. Melbourne: The University of Melbourne. Available online: https://melbourne.figshare.com/articles/Database_of_Embodied_ Energy_and_Water_Values_for_Materials/4595623 (accessed on 15 October 2019). 